\title{
Voltage-gated sodium channels (version 2019.4) in the IUPHAR/BPS Guide to Pharmacology Database
}

\author{
William A. Catterall ${ }^{1}$, Alan L. Goldin² and Stephen G. Waxman ${ }^{3}$ \\ 1. University of Washington, USA \\ 2. University of California, USA \\ 3. Yale University, USA
}

\begin{abstract}
Sodium channels are voltage-gated sodium-selective ion channels present in the membrane of most excitable cells. Sodium channels comprise of one pore-forming $\alpha$ subunit, which may be associated with either one or two $\beta$ subunits [176]. $\alpha$-Subunits consist of four homologous domains (I-IV), each containing six transmembrane segments (S1-S6) and a pore-forming loop. The positively charged fourth transmembrane segment (S4) acts as a voltage sensor and is involved in channel gating. The crystal structure of the bacterial NavAb channel has revealed a number of novel structural features compared to earlier potassium channel structures including a short selectivity filter with ion selectivity determined by interactions with glutamate side chains [268]. Interestingly, the pore region is penetrated by fatty acyl chains that extend into the central cavity which may allow the entry of small, hydrophobic pore-blocking drugs [268]. Auxiliary $\beta 1, \beta 2, \beta 3$ and $\beta 4$ subunits consist of a large extracellular $\mathrm{N}$-terminal domain, a single transmembrane segment and a shorter cytoplasmic domain.
\end{abstract}

The nomenclature for sodium channels was proposed by Goldinet al., (2000) [143] and approved by the NC-IUPHAR Subcommittee on sodium channels (Catterallet al., 2005, [51]).

\section{Contents}

This is a citation summary for Voltage-gated sodium channels in the Guide to Pharmacology database (GtoPdb). It exists purely as an adjunct to the database to facilitate the recognition of citations to and from the database by citation analyzers. Readers will almost certainly want to visit the relevant sections of the database which are given here under database links.

GtoPdb is an expert-driven guide to pharmacological targets and the substances that act on them. GtoPdb is a reference work which is most usefully represented as an on-line database. As in any publication this work should be appropriately cited, and the papers it cites should also be recognized. This document provides a citation for the relevant parts of the database, and also provides a reference list for the research cited by those parts.

Please note that the database version for the citations given in GtoPdb are to the most recent preceding version in which the family or its subfamilies and targets were substantially changed. The links below are to the current version. If you need to consult the cited version, rather than the most recent version, please contact the GtoPdb curators. 


\section{Database links}

Voltage-gated sodium channels

http://www.guidetopharmacology.org/GRAC/FamilyDisplayForward?familyld=82

Introduction to Voltage-gated sodium channels

http://www.guidetopharmacology.org/GRAC/FamilyIntroductionForward?familyld=82

Channels and Subunits

$$
\begin{aligned}
& \mathrm{Na}_{\mathrm{v}} 1.1 \\
& \text { http://www.guidetopharmacology.org/GRAC/ObjectDisplayForward?objectld=578 } \\
& \mathrm{Na}_{\mathrm{v}} 1.2 \\
& \text { http://www.guidetopharmacology.org/GRAC/ObjectDisplayForward?objectld=579 } \\
& \mathrm{Na}_{\mathrm{v}} 1.3 \\
& \text { http://www.guidetopharmacology.org/GRAC/ObjectDisplayForward?objectld=580 } \\
& \mathrm{Na}_{\mathrm{v}} 1.4 \\
& \text { http://www.guidetopharmacology.org/GRAC/ObjectDisplayForward?objectld=581 } \\
& \mathrm{Na}_{\mathrm{v}} 1.5 \\
& \text { http://www.guidetopharmacology.org/GRAC/ObjectDisplayForward?objectld=582 } \\
& \mathrm{Na}_{\mathrm{v}} 1.6 \\
& \text { http://www.guidetopharmacology.org/GRAC/ObjectDisplayForward?objectld=583 } \\
& \mathrm{Na}_{\mathrm{v}} 1.7 \\
& \text { http://www.guidetopharmacology.org/GRAC/ObjectDisplayForward?objectld=584 } \\
& \mathrm{Na}_{\mathrm{v}} 1.8 \\
& \text { http://www.guidetopharmacology.org/GRAC/ObjectDisplayForward?objectld=585 } \\
& \mathrm{Na}_{\mathrm{v}} 1.9 \\
& \text { http://www.guidetopharmacology.org/GRAC/ObjectDisplayForward?objectld=586 }
\end{aligned}
$$

\section{References}

1. Abdelsayed M, Sokolov S and Ruben PC. (2013) A thermosensitive mutation alters the effects of lacosamide on slow inactivation in neuronal voltage-gated sodium channels, NaV1.2. Front Pharmacol 4: 121 [PMID:24065921]

2. Ackerman MJ, Siu BL, Sturner WQ, Tester DJ, Valdivia CR, Makielski JC and Towbin JA. (2001) Postmortem molecular analysis of SCN5A defects in sudden infant death syndrome. JAMA 286: 2264-9 [PMID:11710892]

3. Ahmed CM, Ware DH, Lee SC, Patten CD, Ferrer-Montiel AV, Schinder AF, McPherson JD, WagnerMcPherson CB, Wasmuth JJ and Evans GA et al.. (1992) Primary structure, chromosomal localization, and functional expression of a voltage-gated sodium channel from human brain. Proc. Natl. Acad. Sci. U.S.A. 89: 8220-4 [PMID:1325650]

4. Ahn HS, Dib-Hajj SD, Cox JJ, Tyrrell L, Elmslie FV, Clarke AA, Drenth JP, Woods CG and Waxman SG. (2010) A new Nav1.7 sodium channel mutation I234T in a child with severe pain. Eur J Pain 14: 944-50 [PMID:20385509]

5. Akopian AN, Sivilotti L and Wood JN. (1996) A tetrodotoxin-resistant voltage-gated sodium channel expressed by sensory neurons. Nature 379: 257-62 [PMID:8538791]

6. Akopian AN, Souslova V, England S, Okuse K, Ogata N, Ure J, Smith A, Kerr BJ, McMahon SB and Boyce $S$ et al.. (1999) The tetrodotoxin-resistant sodium channel SNS has a specialized function in pain pathways. Nat. Neurosci. 2: 541-8 [PMID:10448219]

7. Amaya F, Wang H, Costigan M, Allchorne AJ, Hatcher JP, Egerton J, Stean T, Morisset V, Grose D, Gunthorpe MJ, Chessell IP, Tate S, Green PJ and Woolf CJ. (2006) The voltage-gated sodium channel $\mathrm{Na}(\mathrm{v}) 1.9$ is an effector of peripheral inflammatory pain hypersensitivity. J. Neurosci. 26: 12852-60 [PMID:17167076] 
8. Ambrose C, Cheng S, Fontaine B, Nadeau JH, MacDonald M and Gusella JF. (1992) The alpha-subunit of the skeletal muscle sodium channel is encoded proximal to Tk-1 on mouse chromosome 11. Mamm. Genome 3: 151-5 [PMID:1352160]

9. Arisawa $T$, Tahara $T$, Shiroeda $H$, Minato $T$, Matsue $Y$, Saito $T$, Fukuyama $T$, Otsuka $T$, Fukumura $A$ and Nakamura M et al.. (2013) Genetic polymorphisms of SCN10A are associated with functional dyspepsia in Japanese subjects. J. Gastroenterol. 48: 73-80 [PMID:22618805]

10. Armstrong CM and Bezanilla F. (1973) Currents related to movement of the gating particles of the sodium channels. Nature 242: 459-61 [PMID:4700900]

11. Arnestad M, Crotti L, Rognum TO, Insolia R, Pedrazzini M, Ferrandi C, Vege A, Wang DW, Rhodes TE, George AL and Schwartz PJ. (2007) Prevalence of long-QT syndrome gene variants in sudden infant death syndrome. Circulation 115: 361-7 [PMID:17210839]

12. Arzel-Hézode M, Sternberg D, Tabti N, Vicart S, Goizet C, Eymard B, Fontaine B and Fournier E. (2010) Homozygosity for dominant mutations increases severity of muscle channelopathies. Muscle Nerve 41: 470-7 [PMID:19882638]

13. Auld VJ, Goldin AL, Krafte DS, Marshall J, Dunn JM, Catterall WA, Lester HA, Davidson N and Dunn RJ. (1988) A rat brain $\mathrm{Na}+$ channel alpha subunit with novel gating properties. Neuron 1: 449-61 [PMID:2856097]

14. Bagal SK, Chapman ML, Marron BE, Prime R, Storer RI and Swain NA. (2014) Recent progress in sodium channel modulators for pain. Bioorg. Med. Chem. Lett. 24: 3690-9 [PMID:25060923]

15. Bagnéris C, DeCaen PG, Naylor CE, Pryde DC, Nobeli I, Clapham DE and Wallace BA. (2014) Prokaryotic NavMs channel as a structural and functional model for eukaryotic sodium channel antagonism. Proc. Natl. Acad. Sci. U.S.A. 111: 8428-33 [PMID:24850863]

16. Baker MD, Chandra SY, Ding Y, Waxman SG and Wood JN. (2003) GTP-induced tetrodotoxin-resistant $\mathrm{Na}+$ current regulates excitability in mouse and rat small diameter sensory neurones. J. Physiol. (Lond.) 548: 373-82 [PMID:12651922]

17. Barela AJ, Waddy SP, Lickfett JG, Hunter J, Anido A, Helmers SL, Goldin AL and Escayg A. (2006) An epilepsy mutation in the sodium channel SCN1A that decreases channel excitability. J. Neurosci. 26: 271423 [PMID:16525050]

18. Barros J, Ferreira A, Brandão AF, Lemos C, Correia F, Damásio J, Tuna A, Sequeiros J, Coutinho P and Alonso I et al.. (2014) Familial hemiplegic migraine due to L263V SCN1A mutation: discordance for epilepsy between two kindreds from Douro Valley. Cephalalgia 34: 1015-20 [PMID:24646837]

19. Bechi G, Scalmani P, Schiavon E, Rusconi R, Franceschetti S and Mantegazza M. (2012) Pure haploinsufficiency for Dravet syndrome $\mathrm{Na}(\mathrm{V}) 1.1$ (SCN1A) sodium channel truncating mutations. Epilepsia 53: 87-100 [PMID:22150645]

20. Beckers MC, Ernst E, Belcher S, Howe J, Levenson R and Gros P. (1996) A new sodium channel alphasubunit gene (Scn9a) from Schwann cells maps to the Scn1a, Scn2a, Scn3a cluster of mouse chromosome 2. Genomics 36: 202-5 [PMID:8812438]

21. Beckh S, Noda M, Lübbert $H$ and Numa S. (1989) Differential regulation of three sodium channel messenger RNAs in the rat central nervous system during development. EMBO J. 8: 3611-6 [PMID:2555170]

22. Belardinelli L, Rajamani S and Zeng D.. (2015) Compound and methods for treating long qt syndrome. Patent number: US20150038489 A1.

23. Bendahhou S, Cummins TR, Kula RW, Fu YH and Ptácek LJ. (2002) Impairment of slow inactivation as a common mechanism for periodic paralysis in DIIS4-S5. Neurology 58: 1266-72 [PMID:11971097]

24. Bendahhou S, Cummins TR, Kwiecinski H, Waxman SG and Ptácek LJ. (1999) Characterization of a new sodium channel mutation at arginine 1448 associated with moderate Paramyotonia congenita in humans. J. Physiol. (Lond.) 518 ( Pt 2): 337-44 [PMID:10381583]

25. Bennett ES. (2004) Channel activation voltage alone is directly altered in an isoform-specific manner by $\mathrm{Na}(\mathrm{v} 1.4)$ and $\mathrm{Na}(\mathrm{v} 1.5)$ cytoplasmic linkers. J. Membr. Biol. 197: 155-68 [PMID:15042347]

26. Benson DW, Wang DW, Dyment M, Knilans TK, Fish FA, Strieper MJ, Rhodes TH and George Jr AL. 
(2003) Congenital sick sinus syndrome caused by recessive mutations in the cardiac sodium channel gene (SCN5A). J. Clin. Invest. 112: 1019-28 [PMID:14523039]

27. Berkovic SF, Heron SE, Giordano L, Marini C, Guerrini R, Kaplan RE, Gambardella A, Steinlein OK, Grinton BE, Dean JT, Bordo L, Hodgson BL, Yamamoto T, Mulley JC, Zara F and Scheffer IE. (2004) Benign familial neonatal-infantile seizures: characterization of a new sodium channelopathy. Ann. Neurol. 55: 550-7 [PMID:15048894]

28. Biskup C, Zimmer T and Benndorf K. (2004) FRET between cardiac $\mathrm{Na}$ + channel subunits measured with a confocal microscope and a streak camera. Nat. Biotechnol. 22: 220-4 [PMID:14730318]

29. Black JA, Cummins TR, Plumpton C, Chen YH, Hormuzdiar W, Clare JJ and Waxman SG. (1999) Upregulation of a silent sodium channel after peripheral, but not central, nerve injury in DRG neurons. J. Neurophysiol. 82: 2776-85 [PMID:10561444]

30. Black JA, Dib-Hajj S, Baker D, Newcombe J, Cuzner ML and Waxman SG. (2000) Sensory neuronspecific sodium channel SNS is abnormally expressed in the brains of mice with experimental allergic encephalomyelitis and humans with multiple sclerosis. Proc. Natl. Acad. Sci. U.S.A. 97: 11598-602 [PMID:11027357]

31. Black JA and Waxman SG. (2013) Noncanonical roles of voltage-gated sodium channels.Neuron 80: 28091 [PMID:24139034]

32. Blair NT and Bean BP. (2002) Roles of tetrodotoxin (TTX)-sensitive Na+ current, TTX-resistant Na+ current, and $\mathrm{Ca} 2+$ current in the action potentials of nociceptive sensory neurons. J. Neurosci. 22: 1027790 [PMID:12451128]

33. Boiko T, Rasband MN, Levinson SR, Caldwell JH, Mandel G, Trimmer JS and Matthews G. (2001) Compact myelin dictates the differential targeting of two sodium channel isoforms in the same axon. Neuron 30: 91-104 [PMID:11343647]

34. Bosmans F, Maertens C, Verdonck F and Tytgat J. (2004) The poison Dart frog's batrachotoxin modulates Nav1.8. FEBS Lett. 577: 245-8 [PMID:15527793]

35. Bossu A, Houtman MJC, Meijborg VMF, Varkevisser R, Beekman HDM, Dunnink A, de Bakker JMT, Mollova N, Rajamani S and Belardinelli $L$ et al.. (2018) Selective late sodium current inhibitor GS-458967 suppresses Torsades de Pointes by mostly affecting perpetuation but not initiation of the arrhythmia. Br. J. Pharmacol. 175: 2470-2482 [PMID:29582428]

36. Bouhours M, Sternberg D, Davoine CS, Ferrer X, Willer JC, Fontaine B and Tabti N. (2004) Functional characterization and cold sensitivity of T1313A, a new mutation of the skeletal muscle sodium channel causing paramyotonia congenita in humans. J. Physiol. (Lond.) 554: 635-47 [PMID:14617673]

37. Brackenbury WJ and Isom LL. (2011) Na Channel $\beta$ Subunits: Overachievers of the lon Channel Family. Front Pharmaco/2: 53 [PMID:22007171]

38. Bricelj VM, Connell L, Konoki K, Macquarrie SP, Scheuer T, Catterall WA and Trainer VL. (2005) Sodium channel mutation leading to saxitoxin resistance in clams increases risk of PSP. Nature 434: 763-7 [PMID:15815630]

39. Bulman DE, Scoggan KA, van Oene MD, Nicolle MW, Hahn AF, Tollar LL and Ebers GC. (1999) A novel sodium channel mutation in a family with hypokalemic periodic paralysis. Neurology 53: 1932-6 [PMID:10599760]

40. Burbidge SA, Dale TJ, Powell AJ, Whitaker WR, Xie XM, Romanos MA and Clare JJ. (2002) Molecular cloning, distribution and functional analysis of the $N A(V) 1.6$. Voltage-gated sodium channel from human brain. Brain Res. Mol. Brain Res. 103: 80-90 [PMID:12106694]

41. Burgess DL, Kohrman DC, Galt J, Plummer NW, Jones JM, Spear B and Meisler MH. (1995) Mutation of a new sodium channel gene, Scn8a, in the mouse mutant 'motor endplate disease'. Nat. Genet. 10: 461-5 [PMID:7670495]

42. Caldwell JH, Schaller KL, Lasher RS, Peles E and Levinson SR. (2000) Sodium channel $\mathrm{Na}(\mathrm{v}) 1.6$ is localized at nodes of ranvier, dendrites, and synapses. Proc. Natl. Acad. Sci. U.S.A. 97: 5616-20 [PMID:10779552]

43. Cannon SC. (2002) An expanding view for the molecular basis of familial periodic paralysis.Neuromuscul. 
Disord. 12: 533-43 [PMID:12117476]

44. Cardenas CG, Del Mar LP, Cooper BY and Scroggs RS. (1997) 5HT4 receptors couple positively to tetrodotoxin-insensitive sodium channels in a subpopulation of capsaicin-sensitive rat sensory neurons. $J$. Neurosci. 17: 7181-9 [PMID:9295364]

45. Carle T, Lhuillier L, Luce S, Sternberg D, Devuyst O, Fontaine B and Tabti N. (2006) Gating defects of a novel $\mathrm{Na}+$ channel mutant causing hypokalemic periodic paralysis. Biochem. Biophys. Res. Commun. 348: 653-61 [PMID:16890191]

46. Catterall WA. (2010) Signaling complexes of voltage-gated sodium and calcium channels.Neurosci. Lett. 486: 107-16 [PMID:20816922]

47. Catterall WA. (2010) Ion channel voltage sensors: structure, function, and pathophysiology.Neuron 67: 915-28 [PMID:20869590]

48. Catterall WA. (2000) From ionic currents to molecular mechanisms: the structure and function of voltagegated sodium channels. Neuron 26: 13-25 [PMID:10798388]

49. Catterall WA. (2014) Sodium channels, inherited epilepsy, and antiepileptic drugs Annu. Rev. Pharmacol. Toxicol. 54: 317-38 [PMID:24392695]

50. Catterall WA, Dib-Hajj S, Meisler MH and Pietrobon D. (2008) Inherited neuronal ion channelopathies: new windows on complex neurological diseases. J. Neurosci. 28: 11768-77 [PMID:19005038]

51. Catterall WA, Goldin AL and Waxman SG. (2005) International Union of Pharmacology. XLVII. Nomenclature and structure-function relationships of voltage-gated sodium channels. Pharmacol. Rev. 57: 397-409 [PMID:16382098]

52. Catterall WA, Morrow CS, Daly JW and Brown GB. (1981) Binding of batrachotoxinin A 20-alpha-benzoate to a receptor site associated with sodium channels in synaptic nerve ending particles. J. Biol. Chem. 256: 8922-7 [PMID:6114956]

53. Catterall WA and Swanson TM. (2015) Structural basis for pharmacology of voltage-gated sodium and calcium channels. Mol. Pharmacol. 88: 141-50 [PMID:25848093]

54. Catterall WA and Yu FH. (2006) Painful channels. Neuron 52: 743-4 [PMID:17145494]

55. Catterall WA and Zheng N. (2015) Deciphering voltage-gated $\mathrm{Na}(+)$ and $\mathrm{Ca}(2+)$ channels by studying prokaryotic ancestors. Trends Biochem. Sci. 40: 526-34 [PMID:26254514]

56. Cestèle $S$ and Catterall WA. (2000) Molecular mechanisms of neurotoxin action on voltage-gated sodium channels. Biochimie 82: 883-92 [PMID:11086218]

57. Cestèle S, Labate A, Rusconi R, Tarantino P, Mumoli L, Franceschetti S, Annesi G, Mantegazza M and Gambardella A. (2013) Divergent effects of the T1174S SCN1A mutation associated with seizures and hemiplegic migraine. Epilepsia 54: 927-35 [PMID:23398611]

58. Cestèle S, Qu Y, Rogers JC, Rochat H, Scheuer T and Catterall WA. (1998) Voltage sensor-trapping: enhanced activation of sodium channels by beta-scorpion toxin bound to the S3-S4 loop in domain II. Neuron 21: 919-31 [PMID:9808476]

59. Chahine M, Bennett PB, George Jr AL and Horn R. (1994) Functional expression and properties of the human skeletal muscle sodium channel. Pflugers Arch. 427: 136-42 [PMID:8058462]

60. Chahine M, Plante E and Kallen RG. (1996) Sea anemone toxin (ATX II) modulation of heart and skeletal muscle sodium channel alpha-subunits expressed in tsA201 cells. J. Membr. Biol. 152: 39-48 [PMID:8660409]

61. Chakka N, Bregman H, Du B, Nguyen HN, Buchanan JL, Feric E, Ligutti J, Liu D, McDermott JS and Zou A et al.. (2012) Discovery and hit-to-lead optimization of pyrrolopyrimidines as potent, state-dependent $\mathrm{Na}(\mathrm{v}) 1.7$ antagonists. Bioorg. Med. Chem. Lett. 22: 2052-62 [PMID:22318156]

62. Chandy KG and Gutman GA. (1993) Nomenclature for mammalian potassium channel genes. Trends Pharmacol. Sci. 14: 434 [PMID:8122319]

63. Cheah CS, Yu FH, Westenbroek RE, Kalume FK, Oakley JC, Potter GB, Rubenstein JL and Catterall WA. (2012) Specific deletion of NaV1.1 sodium channels in inhibitory interneurons causes seizures and premature death in a mouse model of Dravet syndrome. Proc. Natl. Acad. Sci. U.S.A. 109: 14646-51 [PMID:22908258] 
64. Chen H, Lu S, Leipold E, Gordon D, Hansel A and Heinemann SH. (2002) Differential sensitivity of sodium channels from the central and peripheral nervous system to the scorpion toxins Lqh-2 and Lqh-3. Eur. J. Neurosci. 16: 767-70 [PMID:12270053]

65. Chen LQ, Chahine M, Kallen RG, Barchi RL and Horn R. (1992) Chimeric study of sodium channels from rat skeletal and cardiac muscle. FEBS Lett. 309: 253-7 [PMID:1325372]

66. Chen Q, Kirsch GE, Zhang D, Brugada R, Brugada J, Brugada P, Potenza D, Moya A, Borggrefe M and Breithardt $G$ et al.. (1998) Genetic basis and molecular mechanism for idiopathic ventricular fibrillation. Nature 392: 293-6 [PMID:9521325]

67. Chen YH, Dale TJ, Romanos MA, Whitaker WR, Xie XM and Clare JJ. (2000) Cloning, distribution and functional analysis of the type III sodium channel from human brain. Eur. J. Neurosci. 12: 4281-9 [PMID:11122339]

68. Cheng X, Dib-Hajj SD, Tyrrell L, Te Morsche RH, Drenth JP and Waxman SG. (2011) Deletion mutation of sodium channel $\mathrm{Na}(\mathrm{V}) 1.7$ in inherited erythromelalgia: enhanced slow inactivation modulates dorsal root ganglion neuron hyperexcitability. Brain 134: 1972-86 [PMID:21705421]

69. Cheng X, Dib-Hajj SD, Tyrrell L and Waxman SG. (2008) Mutation I136V alters electrophysiological properties of the $\mathrm{Na}(\mathrm{v}) 1.7$ channel in a family with onset of erythromelalgia in the second decade. Mol Pain 4: 1 [PMID:18171466]

70. Cheng X, Dib-Hajj SD, Tyrrell L, Wright DA, Fischer TZ and Waxman SG. (2010) Mutations at opposite ends of the DIII/S4-S5 linker of sodium channel Na V 1.7 produce distinct pain disorders. Mol Pain 6: 24 [PMID:20429905]

71. Chevrier P, Vijayaragavan $\mathrm{K}$ and Chahine M. (2004) Differential modulation of Nav1.7 and Nav1.8 peripheral nerve sodium channels by the local anesthetic lidocaine. Br. J. Pharmacol. 142: 576-84 [PMID:15148257]

72. Choi JS, Boralevi F, Brissaud O, Sánchez-Martín J, Te Morsche RH, Dib-Hajj SD, Drenth JP and Waxman SG. (2011) Paroxysmal extreme pain disorder: a molecular lesion of peripheral neurons. Nat Rev Neurol 7: 51-5 [PMID:21079636]

73. Choi JS, Cheng X, Foster E, Leffler A, Tyrrell L, Te Morsche RH, Eastman EM, Jansen HJ, Huehne K and Nau $C$ et al.. (2010) Alternative splicing may contribute to time-dependent manifestation of inherited erythromelalgia. Brain 133: 1823-35 [PMID:20478850]

74. Choi JS, Dib-Hajj SD and Waxman SG. (2006) Inherited erythermalgia: limb pain from an S4 chargeneutral Na channelopathy. Neurology 67: 1563-7 [PMID:16988069]

75. Choi JS, Zhang L, Dib-Hajj SD, Han C, Tyrrell L, Lin Z, Wang X, Yang Y and Waxman SG. (2009) Mexiletine-responsive erythromelalgia due to a new $\mathrm{Na}(\mathrm{v}) 1.7$ mutation showing use-dependent current falloff. Exp. Neurol. 216: 383-9 [PMID:19162012]

76. Chowdhury S, Chafeev M, Liu S, Sun J, Raina V, Chui R, Young W, Kwan R, Fu J and Cadieux JA. (2011) Discovery of XEN907, a spirooxindole blocker of NaV1.7 for the treatment of pain. Bioorg. Med. Chem. Lett. 21: 3676-81 [PMID:21570288]

77. Claes L, Del-Favero J, Ceulemans B, Lagae L, Van Broeckhoven C and De Jonghe P. (2001) De novo mutations in the sodium-channel gene SCN1A cause severe myoclonic epilepsy of infancy. Am. J. Hum. Genet. 68: 1327-32 [PMID:11359211]

78. Clancy CE and Kass RS. (2002) Defective cardiac ion channels: from mutations to clinical syndromes.J. Clin. Invest. 110: 1075-7 [PMID:12393842]

79. Clare JJ, Tate SN, Nobbs M and Romanos MA. (2000) Voltage-gated sodium channels as therapeutic targets. Drug Discov. Today 5: 506-520 [PMID:11084387]

80. Cohen SA. (1996) Immunocytochemical localization of $\mathrm{rH} 1$ sodium channel in adult rat heart atria and ventricle. Presence in terminal intercalated disks. Circulation 94: 3083-6 [PMID:8989112]

81. Cohen-Armon M and Sokolovsky M. (1993) Evidence for involvement of the voltage-dependent $\mathrm{Na}+$ channel gating in depolarization-induced activation of G-proteins. J. Biol. Chem. 268: 9824-38 [PMID:8387506]

82. Coulter DA, Rafiq A, Shumate M, Gong QZ, DeLorenzo RJ and Lyeth BG. (1996) Brain injury-induced 
enhanced limbic epileptogenesis: anatomical and physiological parallels to an animal model of temporal lobe epilepsy. Epilepsy Res. 26: 81-91 [PMID:8985690]

83. Cox JJ, Reimann F, Nicholas AK, Thornton G, Roberts E, Springell K, Karbani G, Jafri H, Mannan J and Raashid $Y$ et al.. (2006) An SCN9A channelopathy causes congenital inability to experience pain.Nature 444: 894-8 [PMID:17167479]

84. Cribbs LL, Satin J, Fozzard HA and Rogart RB. (1990) Functional expression of the rat heart I Na+ channel isoform. Demonstration of properties characteristic of native cardiac $\mathrm{Na}+$ channels. FEBS Lett. 275: 195-200 [PMID:2175715]

85. Cummins TR, Aglieco F, Renganathan M, Herzog RI, Dib-Hajj SD and Waxman SG. (2001) Nav1.3 sodium channels: rapid repriming and slow closed-state inactivation display quantitative differences after expression in a mammalian cell line and in spinal sensory neurons. J. Neurosci. 21: 5952-61 [PMID:11487618]

86. Cummins TR, Dib-Hajj SD, Black JA, Akopian AN, Wood JN and Waxman SG. (1999) A novel persistent tetrodotoxin-resistant sodium current in SNS-null and wild-type small primary sensory neurons. $J$. Neurosci. 19: RC43 [PMID:10594087]

87. Cummins TR, Dib-Hajj SD and Waxman SG. (2004) Electrophysiological properties of mutant Nav1.7 sodium channels in a painful inherited neuropathy. J. Neurosci. 24: 8232-6 [PMID:15385606]

88. Cummins TR and Waxman SG. (1997) Downregulation of tetrodotoxin-resistant sodium currents and upregulation of a rapidly repriming tetrodotoxin-sensitive sodium current in small spinal sensory neurons after nerve injury. J. Neurosci. 17: 3503-14 [PMID:9133375]

89. Dhar Malhotra J, Chen C, Rivolta I, Abriel H, Malhotra R, Mattei LN, Brosius FC, Kass RS and Isom LL. (2001) Characterization of sodium channel alpha- and beta-subunits in rat and mouse cardiac myocytes. Circulation 103: 1303-10 [PMID:11238277]

90. Dib-Hajj S, Black JA, Felts P and Waxman SG. (1996) Down-regulation of transcripts for Na channel alpha-SNS in spinal sensory neurons following axotomy. Proc. Natl. Acad. Sci. U.S.A. 93: 14950-4 [PMID:8962162]

91. Dib-Hajj SD, Cummins TR, Black JA and Waxman SG. (2007) From genes to pain: Na v 1.7 and human pain disorders. Trends Neurosci. 30: 555-63 [PMID:17950472]

92. Dib-Hajj SD, Cummins TR, Black JA and Waxman SG. (2010) Sodium channels in normal and pathological pain. Annu. Rev. Neurosci. 33: 325-47 [PMID:20367448]

93. Dib-Hajj SD, Estacion M, Jarecki BW, Tyrrell L, Fischer TZ, Lawden M, Cummins TR and Waxman SG. (2008) Paroxysmal extreme pain disorder M1627K mutation in human Nav1.7 renders DRG neurons hyperexcitable. Mol Pain 4: 37 [PMID:18803825]

94. Dib-Hajj SD, Ishikawa K, Cummins TR and Waxman SG. (1997) Insertion of a SNS-specific tetrapeptide in S3-S4 linker of D4 accelerates recovery from inactivation of skeletal muscle voltage-gated Na channel mu1 in HEK293 cells. FEBS Lett. 416: 11-4 [PMID:9369222]

95. Dib-Hajj SD, Rush AM, Cummins TR, Hisama FM, Novella S, Tyrrell L, Marshall L and Waxman SG. (2005) Gain-of-function mutation in Nav1.7 in familial erythromelalgia induces bursting of sensory neurons. Brain 128: 1847-54 [PMID:15958509]

96. Dib-Hajj SD, Tyrrell L, Black JA and Waxman SG. (1998) NaN, a novel voltage-gated Na channel, is expressed preferentially in peripheral sensory neurons and down-regulated after axotomy. Proc. Natl. Acad. Sci. U.S.A. 95: 8963-8 [PMID:9671787]

97. Dib-Hajj SD, Tyrrell L, Cummins TR, Black JA, Wood PM and Waxman SG. (1999) Two tetrodotoxinresistant sodium channels in human dorsal root ganglion neurons. FEBS Lett. 462: 117-20 [PMID:10580103]

98. Dib-Hajj SD, Tyrrell L, Escayg A, Wood PM, Meisler MH and Waxman SG. (1999) Coding sequence, genomic organization, and conserved chromosomal localization of the mouse gene Scn11a encoding the sodium channel NaN. Genomics 59: 309-18 [PMID:10444332]

99. Dib-Hajj SD and Waxman SG. (2010) Isoform-specific and pan-channel partners regulate trafficking and plasma membrane stability; and alter sodium channel gating properties. Neurosci. Lett. 486: 84-91 
[PMID:20817075]

100. Dib-Hajj SD, Yang Y, Black JA and Waxman SG. (2013) The Na(V)1.7 sodium channel: from molecule to man. Nat. Rev. Neurosci. 14: 49-62 [PMID:23232607]

101. Dice MS, Abbruzzese JL, Wheeler JT, Groome JR, Fujimoto E and Ruben PC. (2004) Temperaturesensitive defects in paramyotonia congenita mutants R1448C and T1313M. Muscle Nerve 30: 277-88 [PMID:15318338]

102. Dichgans M, Freilinger T, Eckstein G, Babini E, Lorenz-Depiereux B, Biskup S, Ferrari MD, Herzog J, van den Maagdenberg AM and Pusch $M$ et al.. (2005) Mutation in the neuronal voltage-gated sodium channel SCN1A in familial hemiplegic migraine. Lancet 366: 371-7 [PMID:16054936]

103. Dietrich PS, McGivern JG, Delgado SG, Koch BD, Eglen RM, Hunter JC and Sangameswaran L. (1998) Functional analysis of a voltage-gated sodium channel and its splice variant from rat dorsal root ganglia. $J$. Neurochem. 70: 2262-72 [PMID:9603190]

104. Djouhri L, Fang X, Okuse K, Wood JN, Berry CM and Lawson SN. (2003) The TTX-resistant sodium channel Nav1.8 (SNS/PN3): expression and correlation with membrane properties in rat nociceptive primary afferent neurons. J. Physiol. (Lond.) 550: 739-52 [PMID:12794175]

105. Drenth JP, te Morsche RH, Guillet G, Taieb A, Kirby RL and Jansen JB. (2005) SCN9A mutations define primary erythermalgia as a neuropathic disorder of voltage gated sodium channels. J. Invest. Dermatol.

124: 1333-8 [PMID:15955112]

106. Ertel EA, Campbell KP, Harpold MM, Hofmann F, Mori Y, Perez-Reyes E, Schwartz A, Snutch TP, Tanabe T, Birnbaumer L, Tsien RW and Catterall WA. (2000) Nomenclature of voltage-gated calcium channels. Neuron 25: 533-5 [PMID:10774722]

107. Escayg A and Goldin AL. (2010) Sodium channel SCN1A and epilepsy: mutations and mechanisms. Epilepsia 51: 1650-8 [PMID:20831750]

108. Escayg A, Heils A, MacDonald BT, Haug K, Sander T and Meisler MH. (2001) A novel SCN1A mutation associated with generalized epilepsy with febrile seizures plus--and prevalence of variants in patients with epilepsy. Am. J. Hum. Genet. 68: 866-73 [PMID:11254445]

109. Escayg A, MacDonald BT, Meisler MH, Baulac S, Huberfeld G, An-Gourfinkel I, Brice A, LeGuern E, Moulard B, Chaigne D, Buresi C and Malafosse A. (2000) Mutations of SCN1A, encoding a neuronal sodium channel, in two families with GEFS+2. Nat. Genet. 24: 343-5 [PMID:10742094]

110. Estacion M, Choi JS, Eastman EM, Lin Z, Li Y, Tyrrell L, Yang Y, Dib-Hajj SD and Waxman SG. (2010) Can robots patch-clamp as well as humans? Characterization of a novel sodium channel mutation. J. Physiol. (Lond.) 588: 1915-27 [PMID:20123784]

111. Estacion M, Dib-Hajj SD, Benke PJ, Te Morsche RH, Eastman EM, Macala LJ, Drenth JP and Waxman SG. (2008) NaV1.7 gain-of-function mutations as a continuum: A1632E displays physiological changes associated with erythromelalgia and paroxysmal extreme pain disorder mutations and produces symptoms of both disorders. J. Neurosci. 28: 11079-88 [PMID:18945915]

112. Estacion M, Gasser A, Dib-Hajj SD and Waxman SG. (2010) A sodium channel mutation linked to epilepsy increases ramp and persistent current of Nav1.3 and induces hyperexcitability in hippocampal neurons. Exp. Neurol. 224: 362-8 [PMID:20420834]

113. Estacion M, Han C, Choi JS, Hoeijmakers JG, Lauria G, Drenth JP, Gerrits MM, Dib-Hajj SD, Faber CG and Merkies IS et al.. (2011) Intra- and interfamily phenotypic diversity in pain syndromes associated with a gain-of-function variant of NaV1.7. Mol Pain 7: 92 [PMID:22136189]

114. Estacion M, Harty TP, Choi JS, Tyrrell L, Dib-Hajj SD and Waxman SG. (2009) A sodium channel gene SCN9A polymorphism that increases nociceptor excitability. Ann. Neurol. 66: 862-6 [PMID:20033988]

115. Eubanks J, Srinivasan J, Dinulos MB, Disteche CM and Catterall WA. (1997) Structure and chromosomal localization of the beta2 subunit of the human brain sodium channel. Neuroreport 8: 2775-9 [PMID:9295116]

116. Faber CG, Hoeijmakers JG, Ahn HS, Cheng X, Han C, Choi JS, Estacion M, Lauria G, Vanhoutte EK and Gerrits MM et al.. (2012) Gain of function Nav1.7 mutations in idiopathic small fiber neuropathy Ann. Neurol. 71: 26-39 [PMID:21698661] 
117. Faber CG, Lauria G, Merkies IS, Cheng X, Han C, Ahn HS, Persson AK, Hoeijmakers JG, Gerrits MM and Pierro T et al.. (2012) Gain-of-function Nav1.8 mutations in painful neuropathy.Proc. Natl. Acad. Sci. U.S.A. 109: 19444-9 [PMID:23115331]

118. Fahmi Al, Patel M, Stevens EB, Fowden AL, John JE, Lee K, Pinnock R, Morgan K, Jackson AP and Vandenberg Jl. (2001) The sodium channel beta-subunit SCN3b modulates the kinetics of SCN5a and is expressed heterogeneously in sheep heart. J. Physiol. (Lond.) 537: 693-700 [PMID:11744748]

119. Fang X, Djouhri L, Black JA, Dib-Hajj SD, Waxman SG and Lawson SN. (2002) The presence and role of the tetrodotoxin-resistant sodium channel $\mathrm{Na}(\mathrm{v}) 1.9(\mathrm{NaN})$ in nociceptive primary afferent neurons. $J$. Neurosci. 22: 7425-33 [PMID:12196564]

120. Farmer C, Cox JJ, Fletcher EV, Woods CG, Wood JN and Schorge S. (2012) Splice variants of $\mathrm{Na}(\mathrm{V}) 1.7$ sodium channels have distinct $\beta$ subunit-dependent biophysical properties. PLOS ONE 7: e41750 [PMID:22911851]

121. Farrag KJ, Bhattacharjee A and Docherty RJ. (2008) A comparison of the effects of veratridine on tetrodotoxin-sensitive and tetrodotoxin-resistant sodium channels in isolated rat dorsal root ganglion neurons. Pflugers Arch. 455: 929-38 [PMID:17962978]

122. Fedulova SA, Kostyuk PG and Veselovsky NS. (1991) lonic mechanisms of electrical excitability in rat sensory neurons during postnatal ontogenesis. Neuroscience 41: 303-9 [PMID:1647504]

123. Felts PA, Yokoyama S, Dib-Hajj S, Black JA and Waxman SG. (1997) Sodium channel alpha-subunit mRNAs I, II, III, NaG, Na6 and hNE (PN1): different expression patterns in developing rat nervous system. Brain Res. Mol. Brain Res. 45: 71-82 [PMID:9105672]

124. Ferrera $L$ and Moran O. (2006) Beta1-subunit modulates the Nav1.4 sodium channel by changing the surface charge. Exp Brain Res 172: 139-50 [PMID:16432696]

125. Fertleman CR, Baker MD, Parker KA, Moffatt S, Elmslie FV, Abrahamsen B, Ostman J, Klugbauer N, Wood JN, Gardiner RM and Rees M. (2006) SCN9A mutations in paroxysmal extreme pain disorder: allelic variants underlie distinct channel defects and phenotypes. Neuron 52: 767-74 [PMID:17145499]

126. Fischer TZ, Gilmore ES, Estacion M, Eastman E, Taylor S, Melanson M, Dib-Hajj SD and Waxman SG. (2009) A novel Nav1.7 mutation producing carbamazepine-responsive erythromelalgia. Ann. Neurol. 65 : 733-41 [PMID:19557861]

127. Fjell J, Hjelmström P, Hormuzdiar W, Milenkovic M, Aglieco F, Tyrrell L, Dib-Hajj S, Waxman SG and Black JA. (2000) Localization of the tetrodotoxin-resistant sodium channel NaN in nociceptors. Neuroreport 11: 199-202 [PMID:10683857]

128. Fleischhauer R, Mitrovic N, Deymeer F, Lehmann-Horn F and Lerche H. (1998) Effects of temperature and mexiletine on the F1473S Na+ channel mutation causing paramyotonia congenita. Pflugers Arch. 436: 757-65 [PMID:9716710]

129. Fletcher EV, Kullmann DM and Schorge S. (2011) Alternative splicing modulates inactivation of type 1 voltage-gated sodium channels by toggling an amino acid in the first S3-S4 linker. J. Biol. Chem. 286: 36700-8 [PMID:21890636]

130. Focken T, Chowdhury S, Zenova A, Grimwood ME, Chabot C, Sheng T, Hemeon I, Decker SM, Wilson M and Bichler $\mathrm{P}$ et al.. (2018) Design of Conformationally Constrained Acyl Sulfonamide Isosteres: Identification of $\mathrm{N}-([1,2,4]$ Triazolo[4,3- a]pyridin-3-yl)methane-sulfonamides as Potent and Selective hNav1.7 Inhibitors for the Treatment of Pain.J. Med. Chem. 61: 4810-4831 [PMID:29737846]

131. Fozzard HA and Hanck DA. (1996) Structure and function of voltage-dependent sodium channels: comparison of brain II and cardiac isoforms. Physiol. Rev. 76: 887-926 [PMID:8757791]

132. Fujiwara T, Sugawara T, Mazaki-Miyazaki E, Takahashi Y, Fukushima K, Watanabe M, Hara K, Morikawa T, Yagi K and Yamakawa K et al.. (2003) Mutations of sodium channel alpha subunit type 1 (SCN1A) in intractable childhood epilepsies with frequent generalized tonic-clonic seizures. Brain 126: 531-46 [PMID:12566275]

133. Gabelli SB, Boto A, Kuhns VH, Bianchet MA, Farinelli F, Aripirala S, Yoder J, Jakoncic J, Tomaselli GF and Amzel LM. (2014) Regulation of the NaV1.5 cytoplasmic domain by calmodulin. Nat Commun 5: 5126 [PMID:25370050] 
134. Gargus JJ and Tournay A. (2007) Novel mutation confirms seizure locus SCN1A is also familial hemiplegic migraine locus FHM3. Pediatr. Neurol. 37: 407-10 [PMID:18021921]

135. Gay S, Dupuis D, Faivre L, Masurel-Paulet A, Labenne M, Colombani M, Soichot P, Huet F, Hainque B and Sternberg $D$ et al.. (2008) Severe neonatal non-dystrophic myotonia secondary to a novel mutation of the voltage-gated sodium channel (SCN4A) gene. Am. J. Med. Genet. A 146: 380-3 [PMID:18203179]

136. Gazina EV, Richards KL, Mokhtar MB, Thomas EA, Reid CA and Petrou S. (2010) Differential expression of exon 5 splice variants of sodium channel alpha subunit mRNAs in the developing mouse brain.

Neuroscience 166: 195-200 [PMID:20006674]

137. George AL. (2005) Inherited disorders of voltage-gated sodium channels.J. Clin. Invest. 115: 1990-9 [PMID:16075039]

138. George Jr AL, Knittle TJ and Tamkun MM. (1992) Molecular cloning of an atypical voltage-gated sodium channel expressed in human heart and uterus: evidence for a distinct gene family. Proc. Natl. Acad. Sci. U.S.A. 89: 4893-7 [PMID:1317577]

139. George Jr AL, Komisarof J, Kallen RG and Barchi RL. (1992) Primary structure of the adult human skeletal muscle voltage-dependent sodium channel. Ann. Neurol. 31: 131-7 [PMID:1315496]

140. Gold MS, Levine JD and Correa AM. (1998) Modulation of TTX-R INa by PKC and PKA and their role in PGE2-induced sensitization of rat sensory neurons in vitro. J. Neurosci. 18: 10345-55 [PMID:9852572]

141. Goldberg YP, MacFarlane J, MacDonald ML, Thompson J, Dube MP, Mattice M, Fraser R, Young C, Hossain S, Pape T, Payne B, Radomski C, Donaldson G, Ives E, Cox J, Younghusband HB, Green R, Duff A, Boltshauser E, Grinspan GA, Dimon JH, Sibley BG, Andria G, Toscano E, Kerdraon J, Bowsher D, Pimstone SN, Samuels ME, Sherrington R and Hayden MR. (2007) Loss-of-function mutations in the Nav1.7 gene underlie congenital indifference to pain in multiple human populations. Clin. Genet. 71: 311-9 [PMID:17470132]

142. Goldin AL. (2001) Resurgence of sodium channel research.Annu. Rev. Physiol. 63: 871-94 [PMID:11181979]

143. Goldin AL, Barchi RL, Caldwell JH, Hofmann F, Howe JR, Hunter JC, Kallen RG, Mandel G, Meisler MH and Netter YB et al.. (2000) Nomenclature of voltage-gated sodium channels. Neuron 28: 365-8 [PMID:11144347]

144. Gong B, Rhodes KJ, Bekele-Arcuri Z and Trimmer JS. (1999) Type I and type II Na(+) channel alphasubunit polypeptides exhibit distinct spatial and temporal patterning, and association with auxiliary subunits in rat brain. J. Comp. Neurol. 412: 342-52 [PMID:10441760]

145. Goral RO, Leipold E, Nematian-Ardestani E and Heinemann SH. (2015) Heterologous expression of NaV1.9 chimeras in various cell systems. Pflugers Arch. 467: 2423-35 [PMID:25916202]

146. Green DS, George AL and Cannon SC. (1998) Human sodium channel gating defects caused by missense mutations in S6 segments associated with myotonia: S804F and V1293I. J. Physiol. (Lond.) 510 ( Pt 3): 685-94 [PMID:9660885]

147. Groome JR, Fujimoto E and Ruben PC. (2005) K-aggravated myotonia mutations at residue G1306 differentially alter deactivation gating of human skeletal muscle sodium channels. Cell. Mol. Neurobiol. 25: 1075-92 [PMID:16392038]

148. Hains BC, Klein JP, Saab CY, Craner MJ, Black JA and Waxman SG. (2003) Upregulation of sodium channel Nav1.3 and functional involvement in neuronal hyperexcitability associated with central neuropathic pain after spinal cord injury. J. Neurosci. 23: 8881-92 [PMID:14523090]

149. Hains BC, Saab CY, Klein JP, Craner MJ and Waxman SG. (2004) Altered sodium channel expression in second-order spinal sensory neurons contributes to pain after peripheral nerve injury. J. Neurosci. 24: 4832-9 [PMID:15152043]

150. Hains BC, Saab CY and Waxman SG. (2005) Changes in electrophysiological properties and sodium channel Nav1.3 expression in thalamic neurons after spinal cord injury. Brain 128: 2359-71 [PMID:16109750]

151. Han C, Dib-Hajj SD, Lin Z, Li Y, Eastman EM, Tyrrell L, Cao X, Yang Y and Waxman SG. (2009) Earlyand late-onset inherited erythromelalgia: genotype-phenotype correlation. Brain 132: 1711-22 
[PMID:19369487]

152. Han C, Hoeijmakers JG, Ahn HS, Zhao P, Shah P, Lauria G, Gerrits MM, te Morsche RH, Dib-Hajj SD and Drenth JP et al.. (2012) Nav1.7-related small fiber neuropathy: impaired slow-inactivation and DRG neuron hyperexcitability. Neurology 78: 1635-43 [PMID:22539570]

153. Han C, Hoeijmakers JG, Liu S, Gerrits MM, te Morsche RH, Lauria G, Dib-Hajj SD, Drenth JP, Faber CG and Merkies IS et al.. (2012) Functional profiles of SCN9A variants in dorsal root ganglion neurons and superior cervical ganglion neurons correlate with autonomic symptoms in small fibre neuropathy. Brain 135: 2613-28 [PMID:22826602]

154. Han C, Rush AM, Dib-Hajj SD, Li S, Xu Z, Wang Y, Tyrrell L, Wang X, Yang Y and Waxman SG. (2006) Sporadic onset of erythermalgia: a gain-of-function mutation in Nav1.7. Ann. Neurol. 59: 553-8 [PMID:16392115]

155. Han C, Yang Y, de Greef BT, Hoeijmakers JG, Gerrits MM, Verhamme C, Qu J, Lauria G, Merkies IS and Faber CG et al.. (2015) The Domain II S4-S5 Linker in Nav1.9: A Missense Mutation Enhances Activation, Impairs Fast Inactivation, and Produces Human Painful Neuropathy. Neuromolecular Med. 17: 158-69 [PMID:25791876]

156. Hartshorne RP and Catterall WA. (1984) The sodium channel from rat brain. Purification and subunit composition. J. Biol. Chem. 259: 1667-75 [PMID:6319405]

157. Hartshorne RP, Messner DJ, Coppersmith JC and Catterall WA. (1982) The saxitoxin receptor of the sodium channel from rat brain. Evidence for two nonidentical beta subunits. J. Biol. Chem. 257: 13888-91 [PMID:6292214]

158. Harty TP, Dib-Hajj SD, Tyrrell L, Blackman R, Hisama FM, Rose JB and Waxman SG. (2006) Na(V)1.7 mutant A863P in erythromelalgia: effects of altered activation and steady-state inactivation on excitability of nociceptive dorsal root ganglion neurons. J. Neurosci. 26: 12566-75 [PMID:17135418]

159. Hedley PL, Jørgensen P, Schlamowitz S, Moolman-Smook J, Kanters JK, Corfield VA and Christiansen M. (2009) The genetic basis of Brugada syndrome: a mutation update. Hum. Mutat. 30: 1256-66 [PMID:19606473]

160. Heine R, Pika U and Lehmann-Horn F. (1993) A novel SCN4A mutation causing myotonia aggravated by cold and potassium. Hum. Mol. Genet. 2: 1349-53 [PMID:8242056]

161. Heinemann SH, Terlau H, Stühmer W, Imoto K and Numa S. (1992) Calcium channel characteristics conferred on the sodium channel by single mutations. Nature 356: 441-3 [PMID:1313551]

162. Heinzen EL, Yoon W, Tate SK, Sen A, Wood NW, Sisodiya SM and Goldstein DB. (2007) Nova2 interacts with a cis-acting polymorphism to influence the proportions of drug-responsive splice variants of SCN1A. Am. J. Hum. Genet. 80: 876-83 [PMID:17436242]

163. Herlenius E, Heron SE, Grinton BE, Keay D, Scheffer IE, Mulley JC and Berkovic SF. (2007) SCN2A mutations and benign familial neonatal-infantile seizures: the phenotypic spectrum. Epilepsia 48: 1138-42 [PMID:17386050]

164. Heron SE, Crossland KM, Andermann E, Phillips HA, Hall AJ, Bleasel A, Shevell M, Mercho S, Seni MH and Guiot MC et al.. (2002) Sodium-channel defects in benign familial neonatal-infantile seizures. Lancet 360: 851-2 [PMID:12243921]

165. Herzog RI, Cummins TR, Ghassemi F, Dib-Hajj SD and Waxman SG. (2003) Distinct repriming and closed-state inactivation kinetics of Nav1.6 and Nav1.7 sodium channels in mouse spinal sensory neurons. J. Physiol. (Lond.) 551: 741-50 [PMID:12843211]

166. Herzog RI, Cummins TR and Waxman SG. (2001) Persistent TTX-resistant Na+ current affects resting potential and response to depolarization in simulated spinal sensory neurons. J. Neurophysiol. 86: 1351-64 [PMID:11535682]

167. Hill RJ, Duff HJ and Sheldon RS. (1989) Class I antiarrhythmic drug receptor: biochemical evidence for state-dependent interaction with quinidine and lidocaine. Mol. Pharmacol. 36: 150-9 [PMID:2546048]

168. Hille B. (2001) Ionic Channels of Excitable Membranes, 3rd Ed. Sinauer Associates Inc.:

169. Hille B. (1977) Local anesthetics: hydrophilic and hydrophobic pathways for the drug-receptor reaction $J$. Gen. Physiol. 69: 497-515 [PMID:300786] 
170. Hirschberg B, Rovner A, Lieberman M and Patlak J. (1995) Transfer of twelve charges is needed to open skeletal muscle Na+ channels. J. Gen. Physiol. 106: 1053-68 [PMID:8786350]

171. HODGKIN AL and HUXLEY AF. (1952) A quantitative description of membrane current and its application to conduction and excitation in nerve. J. Physiol. (Lond.) 117: 500-44 [PMID:12991237]

172. Hoeijmakers JG, Han C, Merkies IS, Macala LJ, Lauria G, Gerrits MM, Dib-Hajj SD, Faber CG and Waxman SG. (2012) Small nerve fibres, small hands and small feet: a new syndrome of pain, dysautonomia and acromesomelia in a kindred with a novel NaV1.7 mutation. Brain 135: 345-58 [PMID:22286749]

173. Holland KD, Kearney JA, Glauser TA, Buck G, Keddache M, Blankston JR, Glaaser IW, Kass RS and Meisler MH. (2008) Mutation of sodium channel SCN3A in a patient with cryptogenic pediatric partial epilepsy. Neurosci. Lett. 433: 65-70 [PMID:18242854]

174. How SW and Cheng AL. (1992) Present status of cancer treatment in Taiwan.Gan To Kagaku Ryoho 19: 1136-8 [PMID:1514825]

175. Huang J, Han C, Estacion M, Vasylyev D, Hoeijmakers JG, Gerrits MM, Tyrrell L, Lauria G, Faber CG and Dib-Hajj SD et al.. (2014) Gain-of-function mutations in sodium channel $\mathrm{Na}(\mathrm{v}) 1.9$ in painful neuropathy. Brain 137: 1627-42 [PMID:24776970]

176. Isom LL. (2001) Sodium channel beta subunits: anything but auxiliary.Neuroscientist 7: $42-54$ [PMID:11486343]

177. Isom LL, De Jongh KS, Patton DE, Reber BF, Offord J, Charbonneau H, Walsh K, Goldin AL and Catterall WA. (1992) Primary structure and functional expression of the beta 1 subunit of the rat brain sodium channel. Science 256: 839-42 [PMID:1375395]

178. Isom LL, Ragsdale DS, De Jongh KS, Westenbroek RE, Reber BF, Scheuer T and Catterall WA. (1995) Structure and function of the beta 2 subunit of brain sodium channels, a transmembrane glycoprotein with a CAM motif. Cell 83: 433-42 [PMID:8521473]

179. Jarecki BW, Sheets PL, Jackson JO and Cummins TR. (2008) Paroxysmal extreme pain disorder mutations within the D3/S4-S5 linker of Nav1.7 cause moderate destabilization of fast inactivation. $J$. Physiol. (Lond.) 586: 4137-53 [PMID:18599537]

180. Jarecki BW, Sheets PL, Xiao Y, Jackson JO and Cummins TR. (2009) Alternative splicing of $\mathrm{Na}(\mathrm{V}) 1.7$ exon 5 increases the impact of the painful PEPD mutant channel I1461T. Channels (Austin) 3: 259-67 [PMID:19633428]

181. Jarvis MF, Honore P, Shieh CC, Chapman M, Joshi S, Zhang XF, Kort M, Carroll W, Marron B and Atkinson $\mathrm{R}$ et al.. (2007) A-803467, a potent and selective Nav1.8 sodium channel blocker, attenuates neuropathic and inflammatory pain in the rat. Proc. Natl. Acad. Sci. U.S.A. 104: 8520-5 [PMID:17483457]

182. Joho RH, Moorman JR, VanDongen AM, Kirsch GE, Silberberg H, Schuster G and Brown AM. (1990) Toxin and kinetic profile of rat brain type III sodium channels expressed in Xenopus oocytes. Brain Res. Mol. Brain Res. 7: 105-13 [PMID:2160038]

183. Jurkat-Rott K and Lehmann-Horn F. (2006) Paroxysmal muscle weakness: the familial periodic paralyses. J. Neurol. 253: 1391-8 [PMID:17139526]

184. Jurkat-Rott K, Mitrovic N, Hang C, Kouzmekine A, laizzo P, Herzog J, Lerche H, Nicole S, Vale-Santos J and Chauveau $\mathrm{D}$ et al.. (2000) Voltage-sensor sodium channel mutations cause hypokalemic periodic paralysis type 2 by enhanced inactivation and reduced current. Proc. Natl. Acad. Sci. U.S.A. 97: 9549-54 [PMID:10944223]

185. Kahn R, Karbat I, Ilan N, Cohen L, Sokolov S, Catterall WA, Gordon D and Gurevitz M. (2009) Molecular requirements for recognition of brain voltage-gated sodium channels by scorpion alpha-toxins. J. Biol. Chem. 284: 20684-91 [PMID:19509294]

186. Kallen RG, Sheng ZH, Yang J, Chen LQ, Rogart RB and Barchi RL. (1990) Primary structure and expression of a sodium channel characteristic of denervated and immature rat skeletal muscle. Neuron 4: 233-42 [PMID:2155010]

187. Kalume F, Yu FH, Westenbroek RE, Scheuer T and Catterall WA. (2007) Reduced sodium current in Purkinje neurons from Nav1.1 mutant mice: implications for ataxia in severe myoclonic epilepsy in infancy. 


\section{J. Neurosci. 27: 11065-74 [PMID:17928448]}

188. Kaplan MR, Cho MH, Ullian EM, Isom LL, Levinson SR and Barres BA. (2001) Differential control of clustering of the sodium channels $\mathrm{Na}(\mathrm{v}) 1.2$ and $\mathrm{Na}(\mathrm{v}) 1.6$ at developing CNS nodes of Ranvier. Neuron $\mathbf{3 0}$ : 105-19 [PMID:11343648]

189. Keating MT and Sanguinetti MC. (2001) Molecular and cellular mechanisms of cardiac arrhythmias.Cell 104: 569-80 [PMID:11239413]

190. Kimura T, Yamaoka K, Kinoshita E, Maejima H, Yuki T, Yakehiro M and Seyama I. (2001) Novel site on sodium channel alpha-subunit responsible for the differential sensitivity of grayanotoxin in skeletal and cardiac muscle. Mol. Pharmacol. 60: 865-72 [PMID:11562450]

191. Klugbauer N, Lacinova L, Flockerzi $V$ and Hofmann F. (1995) Structure and functional expression of a new member of the tetrodotoxin-sensitive voltage-activated sodium channel family from human neuroendocrine cells. EMBO J. 14: 1084-90 [PMID:7720699]

192. Ko SH, Lenkowski PW, Lee HC, Mounsey JP and Patel MK. (2005) Modulation of Na(v)1.5 by beta1-- and beta3-subunit co-expression in mammalian cells. Pflugers Arch. 449: 403-12 [PMID:15455233]

193. Kohrman DC, Smith MR, Goldin AL, Harris J and Meisler MH. (1996) A missense mutation in the sodium channel Scn8a is responsible for cerebellar ataxia in the mouse mutant jolting. J. Neurosci. 16: 5993-9 [PMID:8815882]

194. Koltun DO, Parkhill EQ, Elzein E, Kobayashi T, Notte GT, Kalla R, Jiang RH, Li X, Perry TD and Avila Bet al.. (2016) Discovery of triazolopyridine GS-458967, a late sodium current inhibitor (Late INai) of the cardiac NaV 1.5 channel with improved efficacy and potency relative to ranolazine. Bioorg. Med. Chem. Lett. 26: 3202-3206 [PMID:27080178]

195. Kondratiev A and Tomaselli GF. (2003) Altered gating and local anesthetic block mediated by residues in the I-S6 and II-S6 transmembrane segments of voltage-dependent Na+ channels. Mol. Pharmacol. 64: 741-52 [PMID:12920212]

196. Kozak CA and Sangameswaran L. (1996) Genetic mapping of the peripheral sodium channel genes, Scn9a and Scn10a, in the mouse. Mamm. Genome 7: 787-8 [PMID:8854872]

197. Laezza F, Gerber BR, Lou JY, Kozel MA, Hartman H, Craig AM, Ornitz DM and Nerbonne JM. (2007) The FGF14(F145S) mutation disrupts the interaction of FGF14 with voltage-gated $\mathrm{Na}+$ channels and impairs neuronal excitability. J. Neurosci. 27: 12033-44 [PMID:17978045]

198. Laezza F, Lampert A, Kozel MA, Gerber BR, Rush AM, Nerbonne JM, Waxman SG, Dib-Hajj SD and Ornitz DM. (2009) FGF14 N-terminal splice variants differentially modulate Nav1.2 and Nav1.6-encoded sodium channels. Mol. Cell. Neurosci. 42: 90-101 [PMID:19465131]

199. Lampert A, Dib-Hajj SD, Eastman EM, Tyrrell L, Lin Z, Yang Y and Waxman SG. (2009) Erythromelalgia mutation L823R shifts activation and inactivation of threshold sodium channel Nav1.7 to hyperpolarized potentials. Biochem. Biophys. Res. Commun. 390: 319-24 [PMID:19800314]

200. Lampert A, Dib-Hajj SD, Tyrrell L and Waxman SG. (2006) Size matters: Erythromelalgia mutation S241T in Nav1.7 alters channel gating. J. Biol. Chem. 281: 36029-35 [PMID:17008310]

201. Lampert A, Hains BC and Waxman SG. (2006) Upregulation of persistent and ramp sodium current in dorsal horn neurons after spinal cord injury. Exp Brain Res 174: 660-6 [PMID:16718433]

202. Le Fort D, Safran AB, Picard F, Bouchardy I and Morris MA. (2004) Elicited repetitive daily blindness: a new familial disorder related to migraine and epilepsy. Neurology 63: 348-50 [PMID:15277634]

203. Lee SC, Kim HS, Park YE, Choi YC, Park KH and Kim DS. (2009) Clinical Diversity of SCN4A-MutationAssociated Skeletal Muscle Sodium Channelopathy. J Clin Neurol 5: 186-91 [PMID:20076800]

204. Lehmann-Horn F and Jurkat-Rott K. (1999) Voltage-gated ion channels and hereditary disease.Physiol. Rev. 79: 1317-72 [PMID:10508236]

205. Lehmann-Horn F, Rüdel R and Ricker K. (1993) Non-dystrophic myotonias and periodic paralyses. A European Neuromuscular Center Workshop held 4-6 October 1992, Ulm, Germany. Neuromuscul. Disord. 3: 161-8 [PMID:7689382]

206. Leipold E, Hansel A, Borges A and Heinemann SH. (2006) Subtype specificity of scorpion beta-toxin Tz1 interaction with voltage-gated sodium channels is determined by the pore loop of domain 3. Mol. 
Pharmacol. 70: 340-7 [PMID:16638971]

207. Leipold E, Liebmann L, Korenke GC, Heinrich T, Giesselmann S, Baets J, Ebbinghaus M, Goral RO, Stödberg T and Hennings JC et al.. (2013) A de novo gain-of-function mutation in SCN11A causes loss of pain perception. Nat. Genet. 45: 1399-404 [PMID:24036948]

208. Leipold E, Lu S, Gordon D, Hansel A and Heinemann SH. (2004) Combinatorial interaction of scorpion toxins Lqh-2, Lqh-3, and LqhalphalT with sodium channel receptor sites-3. Mol. Pharmacol. 65: 685-91 [PMID:14978247]

209. Lerche H, Heine R, Pika U, George AL, Mitrovic N, Browatzki M, Weiss T, Rivet-Bastide M, Franke C and Lomonaco M. (1993) Human sodium channel myotonia: slowed channel inactivation due to substitutions for a glycine within the III-IV linker. J. Physiol. (Lond.) 470: 13-22 [PMID:8308722]

210. Lerche H, Mitrovic N, Dubowitz V and Lehmann-Horn F. (1996) Paramyotonia congenita: the R1448P Na+ channel mutation in adult human skeletal muscle. Ann. Neurol. 39: 599-608 [PMID:8619545]

211. Liao Y, Deprez L, Maljevic S, Pitsch J, Claes L, Hristova D, Jordanova A, Ala-Mello S, Bellan-Koch A and Blazevic D et al.. (2010) Molecular correlates of age-dependent seizures in an inherited neonatal-infantile epilepsy. Brain 133: 1403-14 [PMID:20371507]

212. Linford NJ, Cantrell AR, Qu Y, Scheuer T and Catterall WA. (1998) Interaction of batrachotoxin with the local anesthetic receptor site in transmembrane segment IVS6 of the voltage-gated sodium channel. Proc. Natl. Acad. Sci. U.S.A. 95: 13947-52 [PMID:9811906]

213. Liu C, Cummins TR, Tyrrell L, Black JA, Waxman SG and Dib-Hajj SD. (2005) CAP-1A is a novel linker that binds clathrin and the voltage-gated sodium channel $\mathrm{Na}(\mathrm{v}) 1.8$. Mol. Cell. Neurosci. 28: 636-49 [PMID:15797711]

214. Liu G, Yarov-Yarovoy V, Nobbs M, Clare JJ, Scheuer T and Catterall WA. (2003) Differential interactions of lamotrigine and related drugs with transmembrane segment IVS6 of voltage-gated sodium channels. Neuropharmacology 44: 413-22 [PMID:12604088]

215. Lo WL, Donermeyer DL and Allen PM. (2012) A voltage-gated sodium channel is essential for the positive selection of CD4(+) T cells. Nat. Immunol. 13: 880-7 [PMID:22842345]

216. Long SB, Tao X, Campbell EB and MacKinnon R. (2007) Atomic structure of a voltage-dependent K+ channel in a lipid membrane-like environment. Nature 450: 376-82 [PMID:18004376]

217. Lossin C, Wang DW, Rhodes TH, Vanoye CG and George Jr AL. (2002) Molecular basis of an inherited epilepsy. Neuron 34: 877-84 [PMID:12086636]

218. Maertens C, Cuypers E, Amininasab M, Jalali A, Vatanpour H and Tytgat J. (2006) Potent modulation of the voltage-gated sodium channel Nav1.7 by OD1, a toxin from the scorpion Odonthobuthus doriae. Mol. Pharmacol. 70: 405-14 [PMID:16641312]

219. Maier SK, Westenbroek RE, McCormick KA, Curtis R, Scheuer T and Catterall WA. (2004) Distinct subcellular localization of different sodium channel alpha and beta subunits in single ventricular myocytes from mouse heart. Circulation 109: 1421-7 [PMID:15007009]

220. Maier SK, Westenbroek RE, Schenkman KA, Feigl EO, Scheuer T and Catterall WA. (2002) An unexpected role for brain-type sodium channels in coupling of cell surface depolarization to contraction in the heart. Proc. Natl. Acad. Sci. U.S.A. 99: 4073-8 [PMID:11891345]

221. Maier SK, Westenbroek RE, Yamanushi TT, Dobrzynski H, Boyett MR, Catterall WA and Scheuer T. (2003) An unexpected requirement for brain-type sodium channels for control of heart rate in the mouse sinoatrial node. Proc. Natl. Acad. Sci. U.S.A. 100: 3507-12 [PMID:12631690]

222. Makielski JC, Limberis J, Fan Z and Kyle JW. (1999) Intrinsic lidocaine affinity for Na channels expressed in Xenopus oocytes depends on alpha (hH1 vs. rSkM1) and beta 1 subunits. Cardiovasc. Res. 42: 503-9 [PMID:10533585]

223. Makita N, Behr E, Shimizu W, Horie M, Sunami A, Crotti L, Schulze-Bahr E, Fukuhara S, Mochizuki N, Makiyama T, Itoh H, Christiansen M, McKeown P, Miyamoto K, Kamakura S, Tsutsui H, Schwartz PJ, George AL and Roden DM. (2008) The E1784K mutation in SCN5A is associated with mixed clinical phenotype of type 3 long QT syndrome. J. Clin. Invest. 118: 2219-29 [PMID:18451998]

224. Makita N, Sasaki K, Groenewegen WA, Yokota T, Yokoshiki H, Murakami T and Tsutsui H. (2005) 
Congenital atrial standstill associated with coinheritance of a novel SCN5A mutation and connexin 40 polymorphisms. Heart Rhythm 2: 1128-34 [PMID:16188595]

225. Makita N, Shirai N, Nagashima M, Matsuoka R, Yamada Y, Tohse N and Kitabatake A. (1998) A de novo missense mutation of human cardiac $\mathrm{Na}+$ channel exhibiting novel molecular mechanisms of long QT syndrome. FEBS Lett. 423: 5-9 [PMID:9506831]

226. Makiyama T, Akao M, Tsuji K, Doi T, Ohno S, Takenaka K, Kobori A, Ninomiya T, Yoshida H and Takano $M$ et al.. (2005) High risk for bradyarrhythmic complications in patients with Brugada syndrome caused by SCN5A gene mutations. J. Am. Coll. Cardiol. 46: 2100-6 [PMID:16325048]

227. Malhotra JD, Thyagarajan V, Chen C and Isom LL. (2004) Tyrosine-phosphorylated and nonphosphorylated sodium channel beta1 subunits are differentially localized in cardiac myocytes. J. Biol. Chem. 279: 40748-54 [PMID:15272007]

228. Mantegazza M, Yu FH, Catterall WA and Scheuer T. (2001) Role of the C-terminal domain in inactivation of brain and cardiac sodium channels. Proc. Natl. Acad. Sci. U.S.A. 98: 15348-53 [PMID:11742069]

229. Mantegazza M, Yu FH, Powell AJ, Clare JJ, Catterall WA and Scheuer T. (2005) Molecular determinants for modulation of persistent sodium current by G-protein betagamma subunits. J. Neurosci. 25: 3341-9 [PMID:15800189]

230. Marcotte $P$, Chen LQ, Kallen RG and Chahine M. (1997) Effects of Tityus serrulatus scorpion toxin gamma on voltage-gated Na+ channels. Circ. Res. 80: 363-9 [PMID:9048656]

231. Martin MS, Tang B, Papale LA, Yu FH, Catterall WA and Escayg A. (2007) The voltage-gated sodium channel Scn8a is a genetic modifier of severe myoclonic epilepsy of infancy. Hum. Mol. Genet. 16: 2892-9 [PMID:17881658]

232. Matthews E, Labrum R, Sweeney MG, Sud R, Haworth A, Chinnery PF, Meola G, Schorge S, Kullmann DM and Davis MB et al.. (2009) Voltage sensor charge loss accounts for most cases of hypokalemic periodic paralysis. Neurology 72: 1544-7 [PMID:19118277]

233. McClatchey AI, Cannon SC, Slaugenhaupt SA and Gusella JF. (1993) The cloning and expression of a sodium channel beta 1-subunit cDNA from human brain. Hum. Mol. Genet. 2: 745-9 [PMID:8394762]

234. McClatchey AI, McKenna-Yasek D, Cros D, Worthen HG, Kuncl RW, DeSilva SM, Cornblath DR, Gusella JF and Brown RH. (1992) Novel mutations in families with unusual and variable disorders of the skeletal muscle sodium channel. Nat. Genet. 2: 148-52 [PMID:1338909]

235. McClatchey Al, Van den Bergh P, Pericak-Vance MA, Raskind W, Verellen C, McKenna-Yasek D, Rao K, Haines JL, Bird T and Brown Jr RH et al.. (1992) Temperature-sensitive mutations in the III-IV cytoplasmic loop region of the skeletal muscle sodium channel gene in paramyotonia congenita. Cell 68: 769-74 [PMID:1310898]

236. McNulty MM and Hanck DA. (2004) State-dependent mibefradil block of Na+ channels.Mol. Pharmacol. 66: 1652-61 [PMID:15562257]

237. Meadows LS, Chen YH, Powell AJ, Clare JJ and Ragsdale DS. (2002) Functional modulation of human brain Nav1.3 sodium channels, expressed in mammalian cells, by auxiliary beta 1, beta 2 and beta 3 subunits. Neuroscience 114: 745-53 [PMID:12220575]

238. Medeiros-Domingo A, Kaku T, Tester DJ, Iturralde-Torres P, Itty A, Ye B, Valdivia C, Ueda K, CanizalesQuinteros S, Tusié-Luna MT, Makielski JC and Ackerman MJ. (2007) SCN4B-encoded sodium channel beta4 subunit in congenital long-QT syndrome. Circulation 116: 134-42 [PMID:17592081]

239. Michiels JJ, te Morsche RH, Jansen JB and Drenth JP. (2005) Autosomal dominant erythermalgia associated with a novel mutation in the voltage-gated sodium channel alpha subunit Nav1.7. Arch. Neurol. 62: 1587-90 [PMID:16216943]

240. Middleton RE, Warren VA, Kraus RL, Hwang JC, Liu CJ, Dai G, Brochu RM, Kohler MG, Gao YD and Garsky VM et al.. (2002) Two tarantula peptides inhibit activation of multiple sodium channels. Biochemistry 41: 14734-47 [PMID:12475222]

241. Miller TM, Dias da Silva MR, Miller HA, Kwiecinski H, Mendell JR, Tawil R, McManis P, Griggs RC, Angelini C, Servidei S, Petajan J, Dalakas MC, Ranum LP, Fu YH and Ptácek LJ. (2004) Correlating phenotype and genotype in the periodic paralyses. Neurology 63: 1647-55 [PMID:15534250] 
242. Minassian NA, Gibbs A, Shih AY, Liu Y, Neff RA, Sutton SW, Mirzadegan T, Connor J, Fellows R and Husovsky $M$ et al.. (2013) Analysis of the structural and molecular basis of voltage-sensitive sodium channel inhibition by the spider toxin huwentoxin-IV ( $\mu$-TRTX-Hh2a). J. Biol. Chem. 288: 22707-20 [PMID:23760503]

243. Minett MS, Nassar MA, Clark AK, Passmore G, Dickenson AH, Wang F, Malcangio M and Wood JN. (2012) Distinct Nav1.7-dependent pain sensations require different sets of sensory and sympathetic neurons. Nat Commun 3: 791 [PMID:22531176]

244. Mitrović N, George AL, Lerche H, Wagner S, Fahlke C and Lehmann-Horn F. (1995) Different effects on gating of three myotonia-causing mutations in the inactivation gate of the human muscle sodium channel. J. Physiol. (Lond.) 487 ( Pt 1): 107-14 [PMID:7473241]

245. Mohler PJ, Rivolta I, Napolitano C, LeMaillet G, Lambert S, Priori SG and Bennett V. (2004) Nav1.5 E1053K mutation causing Brugada syndrome blocks binding to ankyrin-G and expression of Nav1.5 on the surface of cardiomyocytes. Proc. Natl. Acad. Sci. U.S.A. 101: 17533-8 [PMID:15579534]

246. Morgan K, Stevens EB, Shah B, Cox PJ, Dixon AK, Lee K, Pinnock RD, Hughes J, Richardson PJ and Mizuguchi $\mathrm{K}$ et al.. (2000) beta 3: an additional auxiliary subunit of the voltage-sensitive sodium channel that modulates channel gating with distinct kinetics. Proc. Natl. Acad. Sci. U.S.A. 97: 2308-13 [PMID:10688874]

247. Musa H, Kline CF, Sturm AC, Murphy N, Adelman S, Wang C, Yan H, Johnson BL, Csepe TA and Kilic A et al.. (2015) SCN5A variant that blocks fibroblast growth factor homologous factor regulation causes human arrhythmia. Proc. Natl. Acad. Sci. U.S.A. 112: 12528-33 [PMID:26392562]

248. Márquez MF, Bonny A, Hernández-Castillo E, De Sisti A, Gómez-Flores J, Nava S, Hidden-Lucet F, Iturralde $\mathrm{P}$, Cárdenas $\mathrm{M}$ and Tonet J. (2012) Long-term efficacy of low doses of quinidine on malignant arrhythmias in Brugada syndrome with an implantable cardioverter-defibrillator: a case series and literature review. Heart Rhythm 9: 1995-2000 [PMID:23059185]

249. Nguyen HN, Bregman H, Buchanan JL, Du B, Feric E, Huang L, Li X, Ligutti J, Liu D and Malmberg A et al.. (2012) Discovery and optimization of aminopyrimidinones as potent and state-dependent Nav1.7 antagonists. Bioorg. Med. Chem. Lett. 22: 1055-60 [PMID:22209205]

250. Nilius B, Boldt W and Benndorf K. (1986) Properties of aconitine-modified sodium channels in single cells of mouse ventricular myocardium. Gen. Physiol. Biophys. 5: 473-84 [PMID:2433183]

251. Niu DM, Hwang B, Hwang HW, Wang NH, Wu JY, Lee PC, Chien JC, Shieh RC and Chen YT. (2006) A common SCN5A polymorphism attenuates a severe cardiac phenotype caused by a nonsense SCN5A mutation in a Chinese family with an inherited cardiac conduction defect. J. Med. Genet. 43: 817-21 [PMID:16707561]

252. Noda M and Hiyama TY. (2015) The $\mathrm{Na}(\mathrm{x})$ Channel: What It Is and What It DoesNeuroscientist 21: 399412 [PMID:24962095]

253. Noda M, Ikeda T, Kayano T, Suzuki H, Takeshima H, Kurasaki M, Takahashi H and Numa S. (1986) Existence of distinct sodium channel messenger RNAs in rat brain. Nature 320: 188-92 [PMID:3754035]

254. Noda M, Ikeda T, Suzuki H, Takeshima H, Takahashi T, Kuno M and Numa S. (1986) Expression of functional sodium channels from cloned cDNA. Nature 322: 826-8 [PMID:2427955]

255. Novakovic SD, Tzoumaka E, McGivern JG, Haraguchi M, Sangameswaran L, Gogas KR, Eglen RM and Hunter JC. (1998) Distribution of the tetrodotoxin-resistant sodium channel PN3 in rat sensory neurons in normal and neuropathic conditions. J. Neurosci. 18: 2174-87 [PMID:9482802]

256. Nuss HB, Tomaselli GF and Marbán E. (1995) Cardiac sodium channels (hH1) are intrinsically more sensitive to block by lidocaine than are skeletal muscle (mu 1) channels. J. Gen. Physiol. 106: 1193-209 [PMID:8786356]

257. Ogiwara I, Miyamoto H, Morita N, Atapour N, Mazaki E, Inoue I, Takeuchi T, Itohara S, Yanagawa Y and Obata K et al.. (2007) Nav1.1 localizes to axons of parvalbumin-positive inhibitory interneurons: a circuit basis for epileptic seizures in mice carrying an Scn1a gene mutation. J. Neurosci. 27: 5903-14 [PMID:17537961]

258. Ohmori I, Ouchida M, Ohtsuka Y, Oka E and Shimizu K. (2002) Significant correlation of the SCN1A 
mutations and severe myoclonic epilepsy in infancy. Biochem. Biophys. Res. Commun. 295: 17-23 [PMID:12083760]

259. Okuda S, Kanda F, Nishimoto K, Sasaki R and Chihara K. (2001) Hyperkalemic periodic paralysis and paramyotonia congenita--a novel sodium channel mutation. J. Neurol. 248: 1003-4 [PMID:11757950]

260. Okuse K, Malik-Hall M, Baker MD, Poon WY, Kong H, Chao MV and Wood JN. (2002) Annexin II light chain regulates sensory neuron-specific sodium channel expression. Nature 417: 653-6 [PMID:12050667]

261. Oliveira JS, Redaelli E, Zaharenko AJ, Cassulini RR, Konno K, Pimenta DC, Freitas JC, Clare JJ and Wanke E. (2004) Binding specificity of sea anemone toxins to Nav 1.1-1.6 sodium channels: unexpected contributions from differences in the IV/S3-S4 outer loop. J. Biol. Chem. 279: 33323-35 [PMID:15169781]

262. Orrico A, Galli L, Grosso S, Buoni S, Pianigiani R, Balestri P and Sorrentino V. (2009) Mutational analysis of the SCN1A, SCN1B and GABRG2 genes in 150 Italian patients with idiopathic childhood epilepsies.

Clin. Genet. 75: 579-81 [PMID:19522081]

263. Osteen JD, Herzig V, Gilchrist J, Emrick JJ, Zhang C, Wang X, Castro J, Garcia-Caraballo S, Grundy L and Rychkov GY et al.. (2016) Selective spider toxins reveal a role for the Nav1.1 channel in mechanical pain. Nature 534: 494-9 [PMID:27281198]

264. Pablo JL and Pitt GS. (2016) Fibroblast Growth Factor Homologous Factors: New Roles in Neuronal Health and Disease. Neuroscientist 22: 19-25 [PMID:25492945]

265. Papale LA, Beyer B, Jones JM, Sharkey LM, Tufik S, Epstein M, Letts VA, Meisler MH, Frankel WN and Escayg A. (2009) Heterozygous mutations of the voltage-gated sodium channel SCN8A are associated with spike-wave discharges and absence epilepsy in mice. Hum. Mol. Genet. 18: 1633-41 [PMID:19254928]

266. Park YH and Kim JB. (2010) An atypical phenotype of hypokalemic periodic paralysis caused by a mutation in the sodium channel gene SCN4A. Korean J Pediatr 53: 909-12 [PMID:21189962]

267. Payandeh J, Gamal El-Din TM, Scheuer T, Zheng N and Catterall WA. (2012) Crystal structure of a voltage-gated sodium channel in two potentially inactivated states. Nature 486: 135-9 [PMID:22678296]

268. Payandeh J, Scheuer T, Zheng N and Catterall WA. (2011) The crystal structure of a voltage-gated sodium channel. Nature 475: 353-8 [PMID:21743477]

269. Payne CE, Brown AR, Theile JW, Loucif AJ, Alexandrou AJ, Fuller MD, Mahoney JH, Antonio BM, Gerlach $A C$ and Printzenhoff DM et al.. (2015) A novel selective and orally bioavailable Nav 1.8 channel blocker, PF-01247324, attenuates nociception and sensory neuron excitability. Br. J. Pharmacol. 172: 2654-70 [PMID:25625641]

270. Penzotti JL, Lipkind G, Fozzard HA and Dudley Jr SC. (2001) Specific neosaxitoxin interactions with the $\mathrm{Na}+$ channel outer vestibule determined by mutant cycle analysis. Biophys. J. 80: 698-706 [PMID:11159437]

271. Petitprez S, Tiab L, Chen L, Kappeler L, Rösler KM, Schorderet D, Abriel H and Burgunder JM. (2008) A novel dominant mutation of the Nav1.4 alpha-subunit domain I leading to sodium channel myotonia. Neurology 71: 1669-75 [PMID:19015483]

272. Plummer NW, Galt J, Jones JM, Burgess DL, Sprunger LK, Kohrman DC and Meisler MH. (1998) Exon organization, coding sequence, physical mapping, and polymorphic intragenic markers for the human neuronal sodium channel gene SCN8A. Genomics 54: 287-96 [PMID:9828131]

273. Plummer NW and Meisler MH. (1999) Evolution and diversity of mammalian sodium channel genes. Genomics 57: 323-31 [PMID:10198179]

274. Priest BT, Murphy BA, Lindia JA, Diaz C, Abbadie C, Ritter AM, Liberator P, lyer LM, Kash SF, Kohler MG, Kaczorowski GJ, MacIntyre DE and Martin WJ. (2005) Contribution of the tetrodotoxin-resistant voltagegated sodium channel NaV1.9 to sensory transmission and nociceptive behavior. Proc. Natl. Acad. Sci. U.S.A. 102: 9382-7 [PMID:15964986]

275. Ptacek LJ, Gouw L, Kwieciński H, McManis P, Mendell JR, Barohn RJ, George Jr AL, Barchi RL, Robertson M and Leppert MF. (1993) Sodium channel mutations in paramyotonia congenita and hyperkalemic periodic paralysis. Ann. Neurol. 33: 300-7 [PMID:8388676]

276. Ptácek LJ, George Jr AL, Barchi RL, Griggs RC, Riggs JE, Robertson M and Leppert MF. (1992) 
Mutations in an S4 segment of the adult skeletal muscle sodium channel cause paramyotonia congenita. Neuron 8: 891-7 [PMID:1316765]

277. Ptácek LJ, George Jr AL, Griggs RC, Tawil R, Kallen RG, Barchi RL, Robertson M and Leppert MF. (1991) Identification of a mutation in the gene causing hyperkalemic periodic paralysis. Cell 67: 1021-7 [PMID:1659948]

278. Ptáceek LJ, Tawil R, Griggs RC, Meola G, McManis P, Barohn RJ, Mendell JR, Harris C, Spitzer R and Santiago F et al.. (1994) Sodium channel mutations in acetazolamide-responsive myotonia congenita, paramyotonia congenita, and hyperkalemic periodic paralysis. Neurology 44: 1500-3 [PMID:8058156]

279. Qu Y, Curtis R, Lawson D, Gilbride K, Ge P, DiStefano PS, Silos-Santiago I, Catterall WA and Scheuer T. (2001) Differential modulation of sodium channel gating and persistent sodium currents by the beta1, beta2, and beta3 subunits. Mol. Cell. Neurosci. 18: 570-80 [PMID:11922146]

280. Qu Y, Rogers J, Tanada T, Scheuer T and Catterall WA. (1995) Molecular determinants of drug access to the receptor site for antiarrhythmic drugs in the cardiac Na+ channel. Proc. Natl. Acad. Sci. U.S.A. 92 : 11839-43 [PMID:8524860]

281. Ragsdale DS, McPhee JC, Scheuer T and Catterall WA. (1994) Molecular determinants of statedependent block of $\mathrm{Na}+$ channels by local anesthetics. Science 265: 1724-8 [PMID:8085162]

282. Ragsdale DS, McPhee JC, Scheuer T and Catterall WA. (1996) Common molecular determinants of local anesthetic, antiarrhythmic, and anticonvulsant block of voltage-gated $\mathrm{Na}+$ channels. Proc. Natl. Acad. Sci. U.S.A. 93: 9270-5 [PMID:8799190]

283. Ragsdale DS, Scheuer T and Catterall WA. (1991) Frequency and voltage-dependent inhibition of type IIA $\mathrm{Na}+$ channels, expressed in a mammalian cell line, by local anesthetic, antiarrhythmic, and anticonvulsant drugs. Mol. Pharmacol. 40: 756-65 [PMID:1658608]

284. Reimann F, Cox JJ, Belfer I, Diatchenko L, Zaykin DV, McHale DP, Drenth JP, Dai F, Wheeler J and Sanders F et al.. (2010) Pain perception is altered by a nucleotide polymorphism in SCN9A.Proc. Natl. Acad. Sci. U.S.A. 107: 5148-53 [PMID:20212137]

285. Renganathan M, Cummins TR and Waxman SG. (2001) Contribution of $\mathrm{Na}(\mathrm{v}) 1.8$ sodium channels to action potential electrogenesis in DRG neurons. J. Neurophysiol. 86: 629-40 [PMID:11495938]

286. Renganathan M, Gelderblom M, Black JA and Waxman SG. (2003) Expression of Nav1.8 sodium channels perturbs the firing patterns of cerebellar Purkinje cells. Brain Res. 959: 235-42 [PMID:12493611]

287. Ricker K, Moxley RT, Heine R and Lehmann-Horn F. (1994) Myotonia fluctuans. A third type of muscle sodium channel disease. Arch. Neurol. 51: 1095-102 [PMID:7980103]

288. Rivolta I, Abriel H, Tateyama M, Liu H, Memmi M, Vardas P, Napolitano C, Priori SG and Kass RS. (2001) Inherited Brugada and long QT-3 syndrome mutations of a single residue of the cardiac sodium channel confer distinct channel and clinical phenotypes. J. Biol. Chem. 276: 30623-30 [PMID:11410597]

289. Rogart RB, Cribbs LL, Muglia LK, Kephart DD and Kaiser MW. (1989) Molecular cloning of a putative tetrodotoxin-resistant rat heart $\mathrm{Na}+$ channel isoform. Proc. Natl. Acad. Sci. U.S.A. 86: 8170-4 [PMID:2554302]

290. Rogers JC, Qu Y, Tanada TN, Scheuer T and Catterall WA. (1996) Molecular determinants of high affinity binding of alpha-scorpion toxin and sea anemone toxin in the S3-S4 extracellular loop in domain IV of the $\mathrm{Na}+$ channel alpha subunit. J. Biol. Chem. 271: 15950-62 [PMID:8663157]

291. Rojas CV, Wang JZ, Schwartz LS, Hoffman EP, Powell BR and Brown Jr RH. (1991) A Met-to-Val mutation in the skeletal muscle $\mathrm{Na}+$ channel alpha-subunit in hyperkalaemic periodic paralysis. Nature 354: 387-9 [PMID:1659668]

292. Rong M, Chen J, Tao H, Wu Y, Jiang P, Lu M, Su H, Chi Y, Cai T and Zhao Let al.. (2011) Molecular basis of the tarantula toxin jingzhaotoxin-III ( $\beta$-TRTX-Cj1 $\alpha$ ) interacting with voltage sensors in sodium channel subtype Nav1.5. FASEB J. 25: 3177-85 [PMID:21665957]

293. Rook MB, Bezzina Alshinawi C, Groenewegen WA, van Gelder IC, van Ginneken AC, Jongsma HJ, Mannens MM and Wilde AA. (1999) Human SCN5A gene mutations alter cardiac sodium channel kinetics and are associated with the Brugada syndrome. Cardiovasc. Res. 44: 507-17 [PMID:10690282]

294. Rosenbohm A, Rüdel R and Fahlke C. (1999) Regulation of the human skeletal muscle chloride channel 
hClC-1 by protein kinase C. J. Physiol. (Lond.) 514 ( Pt 3): 677-85 [PMID:9882739]

295. Rosker C, Lohberger B, Hofer D, Steinecker B, Quasthoff S and Schreibmayer W. (2007) The TTX metabolite 4,9-anhydro-TTX is a highly specific blocker of the $\mathrm{Na}(\mathrm{v} 1.6)$ voltage-dependent sodium channel. Am. J. Physiol., Cell Physiol. 293: C783-9 [PMID:17522141]

296. Royer A, van Veen TA, Le Bouter S, Marionneau C, Griol-Charhbili V, Léoni AL, Steenman M, van Rijen HV, Demolombe S, Goddard CA, Richer C, Escoubet B, Jarry-Guichard T, Colledge WH, Gros D, de Bakker JM, Grace AA, Escande D and Charpentier F. (2005) Mouse model of SCN5A-linked hereditary Lenègre's disease: age-related conduction slowing and myocardial fibrosis. Circulation 111: 1738-46 [PMID:15809371]

297. Ruan Y, Liu N, Bloise R, Napolitano C and Priori SG. (2007) Gating properties of SCN5A mutations and the response to mexiletine in long-QT syndrome type 3 patients. Circulation 116: 1137-44 [PMID:17698727]

298. Ruan Y, Liu N and Priori SG. (2009) Sodium channel mutations and arrhythmias.Nat Rev Cardio/ 6: 33748 [PMID:19377496]

299. Rugiero F, Mistry M, Sage D, Black JA, Waxman SG, Crest M, Clerc N, Delmas P and Gola M. (2003) Selective expression of a persistent tetrodotoxin-resistant $\mathrm{Na}+$ current and $\mathrm{NaV} 1.9$ subunit in myenteric sensory neurons. J. Neurosci. 23: 2715-25 [PMID:12684457]

300. Rush AM, Bräu ME, Elliott AA and Elliott JR. (1998) Electrophysiological properties of sodium current subtypes in small cells from adult rat dorsal root ganglia. J. Physiol. (Lond.) 511 ( Pt 3): 771-89 [PMID:9714859]

301. Rush AM, Dib-Hajj SD, Liu S, Cummins TR, Black JA and Waxman SG. (2006) A single sodium channel mutation produces hyper- or hypoexcitability in different types of neurons. Proc. Natl. Acad. Sci. U.S.A. 103: 8245-50 [PMID:16702558]

302. Rush AM and Waxman SG. (2004) PGE2 increases the tetrodotoxin-resistant Nav1.9 sodium current in mouse DRG neurons via G-proteins. Brain Res. 1023: 264-71 [PMID:15374752]

303. Saab CY, Craner MJ, Kataoka Y and Waxman SG. (2004) Abnormal Purkinje cell activity in vivo in experimental allergic encephalomyelitis. Exp Brain Res 158: 1-8 [PMID:15118796]

304. Saab CY, Cummins TR and Waxman SG. (2003) GTP gamma S increases Nav1.8 current in smalldiameter dorsal root ganglia neurons. Exp Brain Res 152: 415-9 [PMID:12898089]

305. Safo P, Rosenbaum T, Shcherbatko A, Choi DY, Han E, Toledo-Aral JJ, Olivera BM, Brehm P and Mandel G. (2000) Distinction among neuronal subtypes of voltage-activated sodium channels by mu-conotoxin PIIIA. J. Neurosci. 20: 76-80 [PMID:10627583]

306. Samad OA, Tan AM, Cheng X, Foster E, Dib-Hajj SD and Waxman SG. (2013) Virus-mediated shRNA Knockdown of $\mathrm{Na}(\mathrm{v}) 1.3$ in Rat Dorsal Root Ganglion Attenuates Nerve Injury-induced Neuropathic Pain. Mol. Ther. 21: 49-56 [PMID:22910296]

307. Sangameswaran L, Fish LM, Koch BD, Rabert DK, Delgado SG, Ilnicka M, Jakeman LB, Novakovic S, Wong K and Sze P et al.. (1997) A novel tetrodotoxin-sensitive, voltage-gated sodium channel expressed in rat and human dorsal root ganglia. J. Biol. Chem. 272: 14805-9 [PMID:9169448]

308. Sarao R, Gupta SK, Auld VJ and Dunn RJ. (1991) Developmentally regulated alternative RNA splicing of rat brain sodium channel mRNAs. Nucleic Acids Res. 19: 5673-9 [PMID:1658739]

309. Schaller KL, Krzemien DM, Yarowsky PJ, Krueger BK and Caldwell JH. (1995) A novel, abundant sodium channel expressed in neurons and glia. J. Neurosci. 15: 3231-42 [PMID:7751906]

310. Schiavon E, Sacco T, Cassulini RR, Gurrola G, Tempia F, Possani LD and Wanke E. (2006) Resurgent current and voltage sensor trapping enhanced activation by a beta-scorpion toxin solely in Nav1.6 channel. Significance in mice Purkinje neurons. J. Biol. Chem. 281: 20326-37 [PMID:16702217]

311. Schlachter K, Gruber-Sedlmayr U, Stogmann E, Lausecker M, Hotzy C, Balzar J, Schuh E, Baumgartner C, Mueller JC and Illig T et al.. (2009) A splice site variant in the sodium channel gene SCN1A confers risk of febrile seizures. Neurology 72: 974-8 [PMID:19289736]

312. Schmalhofer WA, Calhoun J, Burrows R, Bailey T, Kohler MG, Weinglass AB, Kaczorowski GJ, Garcia ML, Koltzenburg M and Priest BT. (2008) ProTx-II, a selective inhibitor of NaV1.7 sodium channels, blocks 
action potential propagation in nociceptors. Mol. Pharmacol. 74: 1476-84 [PMID:18728100]

313. Schott JJ, Alshinawi C, Kyndt F, Probst V, Hoorntje TM, Hulsbeek M, Wilde AA, Escande D, Mannens MM and Le Marec H. (1999) Cardiac conduction defects associate with mutations in SCN5A. Nat. Genet. 23: 20-1 [PMID:10471492]

314. Schwartz PJ, Priori SG, Dumaine R, Napolitano C, Antzelevitch C, Stramba-Badiale M, Richard TA, Berti MR and Bloise R. (2000) A molecular link between the sudden infant death syndrome and the long-QT syndrome. N. Engl. J. Med. 343: 262-7 [PMID:10911008]

315. Schwoerer AP, Scheel $H$ and Friederich P. (2015) A Comparative Analysis of Bupivacaine and Ropivacaine Effects on Human Cardiac SCN5A Channels. Anesth. Analg. 120: 1226-34 [PMID:25692452]

316. Shah BS, Rush AM, Liu S, Tyrrell L, Black JA, Dib-Hajj SD and Waxman SG. (2004) Contactin associates with sodium channel Nav1.3 in native tissues and increases channel density at the cell surface. J. Neurosci. 24: 7387-99 [PMID:15317864]

317. Shah BS, Stevens EB, Pinnock RD, Dixon AK and Lee K. (2001) Developmental expression of the novel voltage-gated sodium channel auxiliary subunit beta3, in rat CNS. J. Physiol. (Lond.) 534: 763-76 [PMID:11483707]

318. Sheets MF and Hanck DA. (1999) Gating of skeletal and cardiac muscle sodium channels in mammalian cells. J. Physiol. (Lond.) 514 ( Pt 2): 425-36 [PMID:9852324]

319. Sheets PL, Heers C, Stoehr T and Cummins TR. (2008) Differential block of sensory neuronal voltagegated sodium channels by lacosamide [(2R)-2-(acetylamino)-N-benzyl-3-methoxypropanamide], lidocaine, and carbamazepine. J. Pharmacol. Exp. Ther. 326: 89-99 [PMID:18378801]

320. Sheldon RS, Cannon NJ and Duff HJ. (1986) Binding of [3H]batrachotoxinin A benzoate to specific sites on rat cardiac sodium channels. Mol. Pharmacol. 30: 617-23 [PMID:2431264]

321. Sheldon RS, Duff HJ, Thakore E and Hill RJ. (1994) Class I antiarrhythmic drugs: allosteric inhibitors of [3H] batrachotoxinin binding to rat cardiac sodium channels. J. Pharmacol. Exp. Ther. 268: 187-94 [PMID:8301556]

322. Sheldon RS, Hill RJ, Cannon NJ and Duff HJ. (1989) Amiodarone: biochemical evidence for binding to a receptor for class I drugs associated with the rat cardiac sodium channel. Circ. Res. 65: 477-82 [PMID:2546697]

323. Shi X, Yasumoto S, Nakagawa E, Fukasawa T, Uchiya S and Hirose S. (2009) Missense mutation of the sodium channel gene SCN2A causes Dravet syndrome. Brain Dev. 31: 758-62 [PMID:19783390]

324. Shields SD, Ahn HS, Yang Y, Han C, Seal RP, Wood JN, Waxman SG and Dib-Hajj SD. (2012) Nav1.8 expression is not restricted to nociceptors in mouse peripheral nervous system. Pain 153: 2017-30 [PMID:22703890]

325. Shields SD, Cheng X, Uçeyler N, Sommer C, Dib-Hajj SD and Waxman SG. (2012) Sodium channel $\mathrm{Na}(\mathrm{v}) 1.7$ is essential for lowering heat pain threshold after burn injury. J. Neurosci. 32: 10819-32 [PMID:22875917]

326. Shin DJ, Jang Y, Park HY, Lee JE, Yang K, Kim E, Bae Y, Kim J, Kim J, Kim SS, Lee MH, Chahine M and Yoon SK. (2004) Genetic analysis of the cardiac sodium channel gene SCN5A in Koreans with Brugada syndrome. J. Hum. Genet. 49: 573-8 [PMID:15338453]

327. Singh NA, Pappas C, Dahle EJ, Claes LR, Pruess TH, De Jonghe P, Thompson J, Dixon M, Gurnett C and Peiffer A et al.. (2009) A role of SCN9A in human epilepsies, as a cause of febrile seizures and as a potential modifier of Dravet syndrome. PLoS Genet. 5: e1000649 [PMID:19763161]

328. Sivilotti L, Okuse K, Akopian AN, Moss S and Wood JN. (1997) A single serine residue confers tetrodotoxin insensitivity on the rat sensory-neuron-specific sodium channel SNS. FEBS Lett. 409: 49-52 [PMID:9199502]

329. Sivilotti LG. (2010) What single-channel analysis tells us of the activation mechanism of ligand-gated channels: the case of the glycine receptor. J. Physiol. (Lond.) 588: 45-58 [PMID:19770192]

330. Sleeper AA, Cummins TR, Dib-Hajj SD, Hormuzdiar W, Tyrrell L, Waxman SG and Black JA. (2000) Changes in expression of two tetrodotoxin-resistant sodium channels and their currents in dorsal root ganglion neurons after sciatic nerve injury but not rhizotomy. J. Neurosci. 20: 7279-89 [PMID:11007885] 
331. Smith MR, Smith RD, Plummer NW, Meisler MH and Goldin AL. (1998) Functional analysis of the mouse Scn8a sodium channel. J. Neurosci. 18: 6093-102 [PMID:9698304]

332. Smith RD and Goldin AL. (1998) Functional analysis of the rat I sodium channel in xenopus oocytes J. Neurosci. 18: 811-20 [PMID:9437003]

333. Smits JP, Koopmann TT, Wilders R, Veldkamp MW, Opthof T, Bhuiyan ZA, Mannens MM, Balser JR, Tan $\mathrm{HL}$ and Bezzina CR et al.. (2005) A mutation in the human cardiac sodium channel (E161K) contributes to sick sinus syndrome, conduction disease and Brugada syndrome in two families. J. Mol. Cell. Cardiol. 38: 969-81 [PMID:15910881]

334. Sokolov S, Scheuer T and Catterall WA. (2007) Gating pore current in an inherited ion channelopathy. Nature 446: 76-8 [PMID:17330043]

335. Staud R, Price DD, Janicke D, Andrade E, Hadjipanayis AG, Eaton WT, Kaplan L and Wallace MR. (2011) Two novel mutations of SCN9A (Nav1.7) are associated with partial congenital insensitivity to pain. Eur J Pain 15: 223-30 [PMID:20692858]

336. Sternberg D, Maisonobe T, Jurkat-Rott K, Nicole S, Launay E, Chauveau D, Tabti N, Lehmann-Horn F, Hainque B and Fontaine B. (2001) Hypokalaemic periodic paralysis type 2 caused by mutations at codon 672 in the muscle sodium channel gene SCN4A. Brain 124: 1091-9 [PMID:11353725]

337. Striano P, Bordo L, Lispi ML, Specchio N, Minetti C, Vigevano F and Zara F. (2006) A novel SCN2A mutation in family with benign familial infantile seizures. Epilepsia 47: 218-20 [PMID:16417554]

338. Stunnenberg BC, Ginjaar HB, Trip J, Faber CG, van Engelen BG and Drost G. (2010) Isolated eyelid closure myotonia in two families with sodium channel myotonia. Neurogenetics 11: 257-60 [PMID:19876661]

339. Stühmer W, Methfessel C, Sakmann B, Noda M and Numa S. (1987) Patch clamp characterization of sodium channels expressed from rat brain cDNA. Eur. Biophys. J. 14: 131-8 [PMID:2435540]

340. Sugawara T, Mazaki-Miyazaki E, Fukushima K, Shimomura J, Fujiwara T, Hamano S, Inoue Y and Yamakawa K. (2002) Frequent mutations of SCN1A in severe myoclonic epilepsy in infancy. Neurology 58: 1122-4 [PMID:11940708]

341. Sun S, Cohen CJ and Dehnhardt CM. (2014) Inhibitors of voltage-gated sodium channel Nav1.7: patent applications since 2010. Pharm Pat Ana/ 3: 509-21 [PMID:25374320]

342. Sun W, Cohen SA and Barchi RL. (1995) Localization of epitopes for monoclonal antibodies directed against the adult rat skeletal muscle sodium channel (rSkM1) using polymerase chain reaction, fusion proteins, and western blotting. Anal. Biochem. 226: 188-91 [PMID:7785772]

343. Sutkowski EM and Catterall WA. (1990) Beta 1 subunits of sodium channels. Studies with subunit-specific antibodies. J. Biol. Chem. 265: 12393-9 [PMID:2165060]

344. Tanaka JC, Eccleston JF and Barchi RL. (1983) Cation selectivity characteristics of the reconstituted voltage-dependent sodium channel purified from rat skeletal muscle sarcolemma. J. Biol. Chem. 258: 7519-26 [PMID:6305944]

345. Tanaka M, Cummins TR, Ishikawa K, Dib-Hajj SD, Black JA and Waxman SG. (1998) SNS Na+ channel expression increases in dorsal root ganglion neurons in the carrageenan inflammatory pain model. Neuroreport 9: 967-72 [PMID:9601651]

346. Tate SK, Depondt C, Sisodiya SM, Cavalleri GL, Schorge S, Soranzo N, Thom M, Sen A, Shorvon SD and Sander JW et al.. (2005) Genetic predictors of the maximum doses patients receive during clinical use of the anti-epileptic drugs carbamazepine and phenytoin. Proc. Natl. Acad. Sci. U.S.A. 102: 5507-12 [PMID:15805193]

347. Tate SK, Singh R, Hung CC, Tai JJ, Depondt C, Cavalleri GL, Sisodiya SM, Goldstein DB and Liou HH. (2006) A common polymorphism in the SCN1A gene associates with phenytoin serum levels at maintenance dose. Pharmacogenet. Genomics 16: 721-6 [PMID:17001291]

348. Terlau H and Stühmer W. (1998) Structure and function of voltage-gated ion channels. Naturwissenschaften 85: 437-44 [PMID:9802045]

349. Theile JW, Jarecki BW, Piekarz AD and Cummins TR. (2011) Nav1.7 mutations associated with paroxysmal extreme pain disorder, but not erythromelalgia, enhance Navbeta4 peptide-mediated 
resurgent sodium currents. J. Physiol. (Lond.) 589: 597-608 [PMID:21115638]

350. Thimmapaya R, Neelands T, Niforatos W, Davis-Taber RA, Choi W, Putman CB, Kroeger PE, Packer J, Gopalakrishnan M, Faltynek CR, Surowy CS and Scott VE. (2005) Distribution and functional characterization of human Nav1.3 splice variants. Eur. J. Neurosci. 22: 1-9 [PMID:16029190]

351. Thompson CH, Kahlig KM and George Jr AL. (2011) SCN1A splice variants exhibit divergent sensitivity to commonly used antiepileptic drugs. Epilepsia 52: 1000-9 [PMID:21453355]

352. Thompson CH, Porter JC, Kahlig KM, Daniels MA and George Jr AL. (2012) Nontruncating SCN1A mutations associated with severe myoclonic epilepsy of infancy impair cell surface expression. J. Biol. Chem. 287: 42001-8 [PMID:23086956]

353. Tikhonov DB and Zhorov BS. (2012) Architecture and pore block of eukaryotic voltage-gated sodium channels in view of NavAb bacterial sodium channel structure. Mol. Pharmacol. 82: 97-104 [PMID:22505150]

354. Toledo-Aral JJ, Moss BL, He ZJ, Koszowski AG, Whisenand T, Levinson SR, Wolf JJ, Silos-Santiago I, Halegoua S and Mandel G. (1997) Identification of PN1, a predominant voltage-dependent sodium channel expressed principally in peripheral neurons. Proc. Natl. Acad. Sci. U.S.A. 94: 1527-32 [PMID:9037087]

355. Trimmer JS, Cooperman SS, Agnew WS and Mandel G. (1990) Regulation of muscle sodium channel transcripts during development and in response to denervation. Dev. Biol. 142: 360-7 [PMID:2175278]

356. Trimmer JS, Cooperman SS, Tomiko SA, Zhou JY, Crean SM, Boyle MB, Kallen RG, Sheng ZH, Barchi $\mathrm{RL}$ and Sigworth FJ et al.. (1989) Primary structure and functional expression of a mammalian skeletal muscle sodium channel. Neuron 3: 33-49 [PMID:2559760]

357. Tsujino A, Maertens C, Ohno K, Shen XM, Fukuda T, Harper CM, Cannon SC and Engel AG. (2003) Myasthenic syndrome caused by mutation of the SCN4A sodium channel. Proc. Natl. Acad. Sci. U.S.A. 100: 7377-82 [PMID:12766226]

358. Tzoumaka E, Tischler AC, Sangameswaran L, Eglen RM, Hunter JC and Novakovic SD. (2000) Differential distribution of the tetrodotoxin-sensitive rPN4/NaCh6/Scn8a sodium channel in the nervous system. $J$. Neurosci. Res. 60: 37-44 [PMID:10723066]

359. Vaeth M and Feske S. (2018) Ion channelopathies of the immune system.Curr. Opin. Immunol. 52: 39-50 [PMID:29635109]

360. Vahedi K, Depienne C, Le Fort D, Riant F, Chaine P, Trouillard O, Gaudric A, Morris MA, Leguern E and Tournier-Lasserve E et al.. (2009) Elicited repetitive daily blindness: a new phenotype associated with hemiplegic migraine and SCN1A mutations. Neurology 72: 1178-83 [PMID:19332696]

361. Vargas E, Yarov-Yarovoy V, Khalili-Araghi F, Catterall WA, Klein ML, Tarek M, Lindahl E, Schulten K, Perozo $E$ and Bezanilla $F$ et al.. (2012) An emerging consensus on voltage-dependent gating from computational modeling and molecular dynamics simulations. J. Gen. Physiol. 140: 587-94 [PMID:23183694]

362. Vatta M, Dumaine R, Varghese G, Richard TA, Shimizu W, Aihara N, Nademanee K, Brugada R, Brugada J, Veerakul G, Li H, Bowles NE, Brugada P, Antzelevitch C and Towbin JA. (2002) Genetic and biophysical basis of sudden unexplained nocturnal death syndrome (SUNDS), a disease allelic to Brugada syndrome. Hum. Mol. Genet. 11: 337-45 [PMID:11823453]

363. Veeramah KR, O'Brien JE, Meisler MH, Cheng X, Dib-Hajj SD, Waxman SG, Talwar D, Girirajan S, Eichler EE and Restifo LL et al.. (2012) De novo pathogenic SCN8A mutation identified by whole-genome sequencing of a family quartet affected by infantile epileptic encephalopathy and SUDEP. Am. J. Hum. Genet. 90: 502-10 [PMID:22365152]

364. Veggiotti P, Cardinali S, Montalenti E, Gatti A and Lanzi G. (2001) Generalized epilepsy with febrile seizures plus and severe myoclonic epilepsy in infancy: a case report of two Italian families. Epileptic Disord 3: 29-32 [PMID:11313220]

365. Venance SL, Cannon SC, Fialho D, Fontaine B, Hanna MG, Ptacek LJ, Tristani-Firouzi M, Tawil R, Griggs $\mathrm{RC}$ and $\mathrm{CINCH}$ investigators. (2006) The primary periodic paralyses: diagnosis, pathogenesis and treatment. Brain 129: 8-17 [PMID:16195244]

366. Vicart S, Sternberg D, Fournier E, Ochsner F, Laforet P, Kuntzer T, Eymard B, Hainque B and Fontaine B. 
(2004) New mutations of SCN4A cause a potassium-sensitive normokalemic periodic paralysis. Neurology 63: 2120-7 [PMID:15596759]

367. Vijayaragavan K, Boutjdir M and Chahine M. (2004) Modulation of Nav1.7 and Nav1.8 peripheral nerve sodium channels by protein kinase A and protein kinase C. J. Neurophysiol. 91: 1556-69 [PMID:14657190]

368. Vijayaragavan K, Powell AJ, Kinghorn IJ and Chahine M. (2004) Role of auxiliary beta1-, beta2-, and beta3-subunits and their interaction with $\mathrm{Na}(\mathrm{v}) 1.8$ voltage-gated sodium channel. Biochem. Biophys. Res. Commun. 319: 531-40 [PMID:15178439]

369. Wagner S, Lerche H, Mitrovic N, Heine R, George AL and Lehmann-Horn F. (1997) A novel sodium channel mutation causing a hyperkalemic paralytic and paramyotonic syndrome with variable clinical expressivity. Neurology 49: 1018-25 [PMID:9339683]

370. Walker JR, Novick PA, Parsons WH, McGregor M, Zablocki J, Pande VS and Du Bois J. (2012) Marked difference in saxitoxin and tetrodotoxin affinity for the human nociceptive voltage-gated sodium channel (Nav1.7) [corrected]. Proc. Natl. Acad. Sci. U.S.A. 109: 18102-7 [PMID:23077250]

371. Wallace RH, Hodgson BL, Grinton BE, Gardiner RM, Robinson R, Rodriguez-Casero V, Sadleir L, Morgan J, Harkin LA and Dibbens LM et al.. (2003) Sodium channel alpha1-subunit mutations in severe myoclonic epilepsy of infancy and infantile spasms. Neurology 61: 765-9 [PMID:14504318]

372. Wallace RH, Scheffer IE, Barnett S, Richards M, Dibbens L, Desai RR, Lerman-Sagie T, Lev D, Mazarib A and Brand $\mathrm{N}$ et al.. (2001) Neuronal sodium-channel alpha1-subunit mutations in generalized epilepsy with febrile seizures plus. Am. J. Hum. Genet.68: 859-65 [PMID:11254444]

373. Wang C, Chung BC, Yan H, Lee SY and Pitt GS. (2012) Crystal structure of the ternary complex of a NaV C-terminal domain, a fibroblast growth factor homologous factor, and calmodulin. Structure 20: $1167-76$ [PMID:22705208]

374. Wang DW, Viswanathan PC, Balser JR, George Jr AL and Benson DW. (2002) Clinical, genetic, and biophysical characterization of SCN5A mutations associated with atrioventricular conduction block. Circulation 105: 341-6 [PMID:11804990]

375. Wang G, Dugas M, Armah BI and Honerjäger P. (1990) Sodium channel comodification with full activator reveals veratridine reaction dynamics. Mol. Pharmacol. 37: 144-8 [PMID:2154667]

376. Wang GK, Quan C and Wang S. (1998) A common local anesthetic receptor for benzocaine and etidocaine in voltage-gated mu1 Na+ channels. Pflugers Arch. 435: 293-302 [PMID:9382945]

377. Wang GK, Russell C and Wang SY. (2004) Mexiletine block of wild-type and inactivation-deficient human skeletal muscle hNav1.4 Na+ channels. J. Physiol. (Lond.) 554: 621-33 [PMID:14608007]

378. Wang GK and Wang SY. (2003) Veratridine block of rat skeletal muscle Nav1.4 sodium channels in the inner vestibule. J. Physiol. (Lond.) 548: 667-75 [PMID:12626674]

379. Wang JZ, Rojas CV, Zhou JH, Schwartz LS, Nicholas H and Hoffman EP. (1992) Sequence and genomic structure of the human adult skeletal muscle sodium channel alpha subunit gene on 17q. Biochem.

Biophys. Res. Commun. 182: 794-801 [PMID:1310396]

380. Wang L, Zellmer SG, Printzenhoff DM and Castle NA. (2018) PF-06526290 can both enhance and inhibit conduction through voltage-gated sodium channels. Br. J. Pharmacol. 175: 2926-2939 [PMID:29791744]

381. Wang Q, Chen S, Chen Q, Wan X, Shen J, Hoeltge GA, Timur AA, Keating MT and Kirsch GE. (2004) The common SCN5A mutation R1193Q causes LQTS-type electrophysiological alterations of the cardiac sodium channel. J. Med. Genet. 41: e66 [PMID:15121794]

382. Wang Q, Shen J, Li Z, Timothy K, Vincent GM, Priori SG, Schwartz PJ and Keating MT. (1995) Cardiac sodium channel mutations in patients with long QT syndrome, an inherited cardiac arrhythmia. Hum. Mol. Genet. 4: 1603-7 [PMID:8541846]

383. Wang Q, Shen J, Splawski I, Atkinson D, Li Z, Robinson JL, Moss AJ, Towbin JA and Keating MT. (1995) SCN5A mutations associated with an inherited cardiac arrhythmia, long QT syndrome. Cell 80: 805-11 [PMID:7889574]

384. Wang SY, Barile M and Wang GK. (2001) A phenylalanine residue at segment D3-S6 in Nav1.4 voltagegated $\mathrm{Na}(+)$ channels is critical for pyrethroid action. Mol. Pharmacol. 60: 620-8 [PMID:11502895]

385. Wang SY and Wang GK. (1998) Point mutations in segment I-S6 render voltage-gated Na+ channels 
resistant to batrachotoxin. Proc. Natl. Acad. Sci. U.S.A. 95: 2653-8 [PMID:9482942]

386. Waxman SG and Dib-Hajj S. (2005) Erythermalgia: molecular basis for an inherited pain syndrome. Trends Mol Med 11: 555-62 [PMID:16278094]

387. Waxman SG, Kocsis JD and Black JA. (1994) Type III sodium channel mRNA is expressed in embryonic but not adult spinal sensory neurons, and is reexpressed following axotomy. J. Neurophysiol. 72: 466-70 [PMID:7965028]

388. Waxman SG, Merkies IS, Gerrits MM, Dib-Hajj SD, Lauria G, Cox JJ, Wood JN, Woods CG, Drenth JP and Faber CG. (2014) Sodium channel genes in pain-related disorders: phenotype-genotype associations and recommendations for clinical use. Lancet Neurol 13: 1152-60 [PMID:25316021]

389. Wei J, Wang DW, Alings M, Fish F, Wathen M, Roden DM and George AL. (1999) Congenital long-QT syndrome caused by a novel mutation in a conserved acidic domain of the cardiac $\mathrm{Na}+$ channel. Circulation 99: 3165-71 [PMID:10377081]

390. Weller CM, Pelzer N, de Vries B, López MA, De Fàbregues O, Pascual J, Arroyo MA, Koelewijn SC, Stam AH and Haan J et al.. (2014) Two novel SCN1A mutations identified in families with familial hemiplegic migraine. Cephalalgia 34: 1062-9 [PMID:24707016]

391. Westenbroek RE, Merrick DK and Catterall WA. (1989) Differential subcellular localization of the RI and RII Na+ channel subtypes in central neurons. Neuron 3: 695-704 [PMID:2561976]

392. Westenbroek RE, Noebels JL and Catterall WA. (1992) Elevated expression of type II Na+ channels in hypomyelinated axons of shiverer mouse brain. J. Neurosci. 12: 2259-67 [PMID:1318958]

393. Whitaker W, Faull R, Waldvogel H, Plumpton C, Burbidge S, Emson P and Clare J. (1999) Localization of the type VI voltage-gated sodium channel protein in human CNS. Neuroreport 10: 3703-9 [PMID:10619670]

394. Whitaker WR, Clare JJ, Powell AJ, Chen YH, Faull RL and Emson PC. (2000) Distribution of voltage-gated sodium channel alpha-subunit and beta-subunit mRNAs in human hippocampal formation, cortex, and cerebellum. J. Comp. Neurol. 422: 123-39 [PMID:10842222]

395. Whitaker WR, Faull RL, Waldvogel HJ, Plumpton CJ, Emson PC and Clare JJ. (2001) Comparative distribution of voltage-gated sodium channel proteins in human brain. Brain Res. Mol. Brain Res. 88: 37-53 [PMID:11295230]

396. Wilson MJ, Yoshikami D, Azam L, Gajewiak J, Olivera BM, Bulaj G and Zhang MM. (2011) $\mu$-Conotoxins that differentially block sodium channels NaV1.1 through 1.8 identify those responsible for action potentials in sciatic nerve. Proc. Natl. Acad. Sci. U.S.A. 108: 10302-7 [PMID:21652775]

397. Wollner DA, Messner DJ and Catterall WA. (1987) Beta 2 subunits of sodium channels from vertebrate brain. Studies with subunit-specific antibodies. J. Biol. Chem. 262: 14709-15 [PMID:2444590]

398. Wright SN. (2002) Comparison of aconitine-modified human heart ( $\mathrm{hH} 1)$ and rat skeletal (mu1) muscle $\mathrm{Na}+$ channels: an important role for external $\mathrm{Na}+$ ions. J. Physiol. (Lond.) 538: 759-71 [PMID:11826163]

399. Wu FF, Takahashi MP, Pegoraro E, Angelini C, Colleselli P, Cannon SC and Hoffman EP. (2001) A new mutation in a family with cold-aggravated myotonia disrupts $\mathrm{Na}(+)$ channel inactivation. Neurology 56: 87884 [PMID:11294924]

400. Xie X, Lancaster B, Peakman T and Garthwaite J. (1995) Interaction of the antiepileptic drug lamotrigine with recombinant rat brain type IIA Na+ channels and with native $\mathrm{Na}+$ channels in rat hippocampal neurones. Pflugers Arch. 430: 437-46 [PMID:7491269]

401. Xu R, Thomas EA, Jenkins M, Gazina EV, Chiu C, Heron SE, Mulley JC, Scheffer IE, Berkovic SF and Petrou S. (2007) A childhood epilepsy mutation reveals a role for developmentally regulated splicing of a sodium channel. Mol. Cell. Neurosci. 35: 292-301 [PMID:17467289]

402. Yamaji N, Little MJ, Nishio H, Billen B, Villegas E, Nishiuchi Y, Tytgat J, Nicholson GM and Corzo G. (2009) Synthesis, solution structure, and phylum selectivity of a spider delta-toxin that slows inactivation of specific voltage-gated sodium channel subtypes. J. Biol. Chem. 284: 24568-82 [PMID:19592486]

403. Yang Y, Wang Y, Li S, Xu Z, Li H, Ma L, Fan J, Bu D, Liu B and Fan Zet al.. (2004) Mutations in SCN9A, encoding a sodium channel alpha subunit, in patients with primary erythermalgia. J. Med. Genet. 41: 171-4 [PMID:14985375] 
404. Yarov-Yarovoy V, Brown J, Sharp EM, Clare JJ, Scheuer T and Catterall WA. (2001) Molecular determinants of voltage-dependent gating and binding of pore-blocking drugs in transmembrane segment IIIS6 of the $\mathrm{Na}(+)$ channel alpha subunit. J. Biol. Chem. 276: 20-7 [PMID:11024055]

405. Yarov-Yarovoy V, DeCaen PG, Westenbroek RE, Pan CY, Scheuer T, Baker D and Catterall WA. (2012) Structural basis for gating charge movement in the voltage sensor of a sodium channel. Proc. Natl. Acad. Sci. U.S.A. 109: E93-102 [PMID:22160714]

406. Yarov-Yarovoy V, McPhee JC, Idsvoog D, Pate C, Scheuer T and Catterall WA. (2002) Role of amino acid residues in transmembrane segments IS6 and IIS6 of the Na+ channel alpha subunit in voltage-dependent gating and drug block. J. Biol. Chem. 277: 35393-401 [PMID:12130650]

407. Yiangou $Y$, Birch R, Sangameswaran L, Eglen R and Anand P. (2000) SNS/PN3 and SNS2/NaN sodium channel-like immunoreactivity in human adult and neonate injured sensory nerves. FEBS Lett. 467: 249-52 [PMID:10675548]

408. Yu FH and Catterall WA. (2004) The VGL-chanome: a protein superfamily specialized for electrical signaling and ionic homeostasis. Sci. STKE 2004: re15 [PMID:15467096]

409. Yu FH, Mantegazza M, Westenbroek RE, Robbins CA, Kalume F, Burton KA, Spain WJ, McKnight GS, Scheuer T and Catterall WA. (2006) Reduced sodium current in GABAergic interneurons in a mouse model of severe myoclonic epilepsy in infancy. Nat. Neurosci. 9: 1142-9 [PMID:16921370]

410. Yu FH, Westenbroek RE, Silos-Santiago I, McCormick KA, Lawson D, Ge P, Ferriera H, Lilly J, DiStefano PS and Catterall WA et al.. (2003) Sodium channel beta4, a new disulfide-linked auxiliary subunit with similarity to beta2. J. Neurosci. 23: 7577-85 [PMID:12930796]

411. Yuan J, Matsuura E, Higuchi Y, Hashiguchi A, Nakamura T, Nozuma S, Sakiyama Y, Yoshimura A, Izumo S and Takashima H. (2013) Hereditary sensory and autonomic neuropathy type IID caused by an SCN9A mutation. Neurology 80: 1641-9 [PMID:23596073]

412. Zaharenko AJ, Schiavon E, Ferreira Jr WA, Lecchi M, de Freitas JC, Richardson M and Wanke E. (2012) Characterization of selectivity and pharmacophores of type 1 sea anemone toxins by screening seven $\mathrm{Na}(\mathrm{v})$ sodium channel isoforms. Peptides 34: 158-67 [PMID:21802465]

413. Zeng D, Kyle JW, Martin RL, Ambler KS and Hanck DA. (1996) Cardiac sodium channels expressed in a peripheral neurotumor-derived cell line, RT4-B8. Am. J. Physiol. 270: C1522-31 [PMID:8967455]

414. Zhang X, Ren W, DeCaen P, Yan C, Tao X, Tang L, Wang J, Hasegawa K, Kumasaka T and He det al.. (2012) Crystal structure of an orthologue of the NaChBac voltage-gated sodium channel. Nature 486: 1304 [PMID:22678295]

415. Zhang XY, Wen J, Yang W, Wang C, Gao L, Zheng LH, Wang T, Ran K, Li Y and Li Xet al.. (2013) Gainof-function mutations in SCN11A cause familial episodic pain. Am. J. Hum. Genet. 93: 957-66 [PMID:24207120]

416. Zimmer T and Benndorf K. (2007) The intracellular domain of the beta 2 subunit modulates the gating of cardiac Na v 1.5 channels. Biophys. J. 92: 3885-92 [PMID:17369409]

417. Zimmer T, Biskup $C$, Bollensdorff $C$ and Benndorf $K$. (2002) The beta1 subunit but not the beta2 subunit colocalizes with the human heart $\mathrm{Na}+$ channel $(\mathrm{hH} 1)$ already within the endoplasmic reticulum. J. Membr. Biol. 186: 13-21 [PMID:11891585]

418. Zimmer T, Bollensdorff C, Haufe V, Birch-Hirschfeld E and Benndorf K. (2002) Mouse heart Na+ channels: primary structure and function of two isoforms and alternatively spliced variants. Am. J. Physiol. Heart Circ. Physiol. 282: H1007-17 [PMID:11834499] 